\title{
The Glycosylphosphatidylinositol Anchor Regulates T Cell Antigen Receptor Induced IL-2 Production
}

\section{Nathalie Vacaresse ${ }^{1 *}$, Alessandra Ferzoco ${ }^{*}$, Dominik Filipp ${ }^{2}$, Yutaka Amemiya1, Arun Seth ${ }^{1,3}$, David Andrews ${ }^{1,4}$, Taroh Kinoshita5, Michael Julius ${ }^{1,6 \#}$}

\author{
${ }^{1}$ Sunnybrook Research Institute, Sunnybrook Health Sciences Centre, Toronto, ON, Canada \\ ${ }^{2}$ Institute of Molecular Genetics of the Czech Academy of Sciences, Prague, Czech Republic \\ ${ }^{3}$ Department of Laboratory Medicine and Pathobiology, University of Toronto, Toronto, ON, Canada \\ ${ }^{4}$ Department of Biochemistry, University of Toronto, Toronto, ON, Canada \\ ${ }^{5}$ Yabumoto Department of Intractable Disease Research, Research Institute for Microbial Diseases, Osaka University, Osaka, Japan \\ ${ }^{6}$ Department of Immunology, University of Toronto, Toronto, ON, Canada \\ Email: \#michael.julius@utoronto.ca
}

How to cite this paper: Vacaresse, N., Ferzoco, A., Filipp, D., Amemiya, Y., Seth, A., Andrews, D., Kinoshita, T. and Julius, M. (2021) The Glycosylphosphatidylinositol Anchor Regulates T Cell Antigen Receptor Induced IL-2 Production. Open Journal of Immunology, 11, 1-24.

https://doi.org/10.4236/oji.2021.111001

Received: January 20, 2021

Accepted: March 9, 2021

Published: March 12, 2021

Copyright $\odot 2021$ by author(s) and Scientific Research Publishing Inc. This work is licensed under the Creative Commons Attribution International License (CC BY 4.0).

http://creativecommons.org/licenses/by/4.0/

\section{(c) (i) Open Access}

\begin{abstract}
Differential contributions of the glycosylphosphatidylinositol (GPI)-anchor and GPI-anchored proteins (GPI-AP) to signalling remain poorly understood. Here we show that GPI-AP deficient murine clones produce on average 18 and 181-fold more IL-2 mRNA and protein, respectively, upon T cell receptor (TCR) stimulation, in a cell-intrinsic fashion. This phenotype is formally attributed to a mutation within the transferase complex that predicates the initial step in GPI-anchor biosynthesis. Conditional disruption of the transferase complex enabled the generation of primary GPI-AP deficient $\mathrm{CD}^{+} \mathrm{T}$ cells, which produce on average 10- and 23-fold more IL-2 mRNA and protein, respectively, upon TCR stimulation. Conditional disruption of the transamidase complex yields GPI-sufficient, GPI-AP deficient primary $\mathrm{CD}^{+} \mathrm{T}$ cells. TCR stimulation of these cells yields levels of IL-2 mRNA and protein ranging from $1-3$ and 3-fold, respectively, of controls. These results provide the first evidence of a profound impact of GPI in the regulation of TCR signalling.
\end{abstract}

\section{Keywords}

GPI Anchor, TCR Regulation, IL-2 Production

\section{Introduction}

The post-translational modification of many proteins with the C-terminal link${ }^{\star}$ Nathalie Vacaresse and Alessandra Ferzoco contributed equally to this paper. 
age of glycosylphosphatidylinositol (GPI) has been conserved throughout evolution. And while this glycolipid structure has a highly conserved core sequence, the diversity among GPI-anchored proteins (GPI-AP) is consistent with their distinct functions which include transmembrane (TM) signalling, intracellular targeting, cellular adhesion and embryonic development [1] [2].

GPI-AP mediated TM signalling is predicated by their coordinated interaction with partnering molecules that couple to intracellular second messenger generating systems. Multiple molecular mechanisms underpin these interactions, inclusive of tethering with TM partners through linkage with the protein ectodomain of the GPI-AP; lectin-like interactions with GPI; lipidic interactions of the GPI-AP with other lipid raft constituents; and less well understood interactions with integrins, protein tyrosine kinases, and heterotrimeric GTP-binding proteins [3] [4] [5] [6] [7].

Whether there are differential, independent or interdependent contributions of the GPI-anchor and the associated protein in supporting GPI-AP signalling remains, in the majority, unclear. There are some notable exceptions that attribute function to the protein moiety, exclusively. Formal proof that the GPI-anchor is dispensable derives from the demonstration that functional integrity is retained in TM forms of the protein [8] [9] [10]. While all GPI-AP share common attributes mediated by GPI, including intracellular trafficking, sorting, transport to plasma membrane [11] and dynamics at the cell surface [12] due to targeting to ordered lipid microdomains [13], there is a paucity of evidence that GPI per se directly impacts cell physiology. A recent paper has established a role for GPI in underpinning an inflammatory response in the generation of a distinct form of paroxysmal nocturnal hemoglobinuria [14].

Here, we formally generalize a role for mature GPI-anchors independent of GPI-AP function to attenuate TCR signalling as measured by induced IL-2 production and DNA synthesis.

\section{Material and Methods}

\subsection{Antibodies and Reagents}

The mAbs specific for Thy-1/CD90 (clone 30H12), CD48 (clone OX78), TCRC $\beta$ (clone H57-597), CD4 (clone GK1.5), CD8 (clone 53-5.8), CD3ع (clone 2C11), IL-2 (S4B6) and anti-IL-2 isotype control (rat IgG2) were affinity-purified from their respective hybridoma cultures and coupled or not to fluorophores or biotin at the Sunnybrook Research Institute Antibody Facility. The fluorophore-labeled $\mathrm{mAb}$ specific for Sca-1/Ly-6A/E (clone D7) was purchased from BD Pharmingen, the $\mathrm{mAb}$ specific for IgM (clone 1B4B1) and the PE-conjugated rat IgG2a isotype control for PD-L1 (clone eBR2a) were purchased from eBiosciences. PE-conjugated rat anti-mouse PD-L1 (clone MIH5), hamster anti mouse PD-1 (clone J43) and hamster IgG2 $\kappa$ isotype control for PD-1 were purchased from BD Biosciences. The T5 mAb against anti- $T$. gondii GPI anchor (clone T5-4E10) was obtained through BEI Resources, Manassas, VA [15]. 
PD-L1-Fc [16] was purchased from R\&D Systems and its isotype control, ChromPure Human IgG was bought from Jackson ImmunoResearch. PD-L1.HIS and CEA.N.HIS were a generous gift from Drs. Jean Gariepy and Aaron Prodeus at the Sunnybrook Research Institute. CEA-N.HIS was expressed and purified as reported previously [17] and used as the control for PD-L1.HIS as they both contain an IgV N-terminal domain and are of similar size. PD-L1.HIS was generated by cloning the extracellular domain of murine PD-L1 into pET30b (Novagen) in frame with a N-terminal histidine tag. After E. coli (BL21 strain, Invitrogen) transformation with this construct, protein expression was induced with $1 \mathrm{mM}$ IPTG for $4 \mathrm{hrs}$ at $37^{\circ} \mathrm{C}$, the cells were lysed and inclusion bodies collected by centrifugation. Pellets were lysed in a buffer containing $8 \mathrm{M}$ urea, $50 \mathrm{mM}$ Tris pH8.0, $250 \mathrm{mM} \mathrm{NaCl}$ and $10 \mathrm{mM} \beta$-mercaptoethanol and the solution was passed through a NI-NTA column. The histidine-tagged protein was eluted in $250 \mathrm{mM}$ imidazole and refolded by dialysis against Tris buffer saline $\mathrm{pH} 8.0$ at $4^{\circ} \mathrm{C}$. The purity of the final recombinant protein was confirmed by SDS-PAGE.

\subsection{Cell Culture}

Clone 2.10 is an IL-2-dependent, $\mathrm{CD}^{-}$murine $\mathrm{T}$ cell clone, specific for ovalbumin (OVA) peptide residues 143 - 157 in the context of $\mathrm{I}^{\mathrm{b}} \mathrm{A}^{\mathrm{b}}$. Clone 2.10 was cultured in serum-free Iscove's Modified Dulbecco's Media (IMDM) base supplemented with $3 \mathrm{ng} / \mathrm{ml}$ recombinant murine IL-2 and 0.1\% L-a-Phosphatidylcholine (soybean lecithin) (Sigma-Aldrich) as previously described [18]. The 2.10 $\mathrm{GPI}^{-}$ variant was isolated from the total 2.10 population based on the loss of CD90 expression. The 2.10 MIEV-0 and MIEV-Pigp variants were obtained by infection of $2.10 \mathrm{GPI}^{-}$clones with the GFP-expressing, bicistronic pMIEV retroviral vector containing or not the Pigp cDNA. Infected $\mathrm{GFP}^{+}$cells were then sorted for CD90 expression (MIEV-Pigp) or not (MIEV-0) to obtained stable infectant populations.

\subsection{Mice}

The Pigat ${ }^{\text {flox }}$ mice were acquired from Dr. Taroh Kinoshita [19] and bred with mice transgenic for the Cre recombinase driven by the $\mathrm{T}$ cell-specific Lck proximal promoter (Jackson Laboratories, stock \#003802) for the generation of Lck-Cre/Piga $a^{f l o x}$ mice. F2 progeny generated T lymphocyte-specific Piga disruption and are referred to as $\mathrm{Piga}^{-/-}$. Mice lacking Cre expression, yet positive for loxP maintained the expression of GPI-AP and are used as littermate control mice, and referred to here as $\mathrm{Piga}^{+/+}$.

Heterozygous mice of strain C57BL/6NTac-PigU ${ }^{\text {tmla(EUCOMM)Hmgu }} /$ lcsOrl were acquired from the European Mouse Mutant Archive (EMMA) and bred with the FLP strain C57BL/6NTac-Gt(ROSA)26Sor ${ }^{\text {tm2(CAG-flpo-EYFP)Ics } / I c s ~ a t ~ t h e ~ T A A M ~}$ (Transgénèse et Archivage d'Animaux Modèles, CNRS, France) to obtain mice bearing the conditional allele Tm1c. To establish the strain on a C57BL/6J background, the Tm1c mice were subsequently backcrossed with C57BL/6J mice ex- 
pressing the Lck driven-Cre recombinase (Jackson Laboratories, stock \#003802) for 5, 8 and 10 generations. The progeny of each of these backcrosses were intercrossed to generate mice with conditional GPI-AP deficiency exclusively on T cells and used in the presented experiments and referred to here as $\mathrm{Pigu}^{-1-}$. Importantly, no differences in experimental results were noted using intercrossed mice at each of these backcross generations. Mice lacking Cre expression, yet positive for loxP maintained the expression of GPI-AP and were used as littermate control mice, and referred to here as $\mathrm{Pigu}^{+/+}$. Genotyping was performed using primers and cycling conditions recommended by EMMA. Backcross 10 C57BL/6J Pigu floxed mice are available at The Jackson Laboratory as stock $\# 034291$.

All mice were housed and bred within specific pathogen-free conditions and all animal procedures were approved by Sunnybrook Research Institute Animal Care Committee, following guidelines of the Canadian Council on Animal Care.

\subsection{CD4 ${ }^{+} / \mathrm{CDB}^{+}$T Cell Purification}

Primary $\mathrm{CD}^{+}$or $\mathrm{CD} 8^{+} \mathrm{T}$ cells were purified from the spleens of $6-12$ weeks old mice using the EasySep ${ }^{\mathrm{TM}} \mathrm{CD} 4^{+}$or $\mathrm{CD}^{+} \mathrm{T}$ cell isolation kit (STEMCELL Technologies). For the purification of $\mathrm{GPI}^{-}$primary $\mathrm{T}$ cells, the selection cocktail was supplemented with biotinylated anti-CD90. T cell preparations were consistently found to be $>92 \%-95 \% \mathrm{CD} 4^{+} \mathrm{TCR} \alpha \beta^{+} \mathrm{CD} 90^{+}$for GPI-AP ${ }^{+}$cells and $>90 \%-95 \%$ $\mathrm{CD} 4^{+} \mathrm{TCR} \alpha \beta^{+} \mathrm{CD} 90^{-}$for $\mathrm{GPI}-\mathrm{AP}^{-}$cells as assessed flow cytometrically.

\subsection{Flow Cytometry}

Flow cytometric analysis was performed following labelling of $1 \times 10^{5}$ cells in $100 \mu \mathrm{l}$ of PBS $+3 \%$ FCS with the indicated fluorochrome-labelled antibodies at concentrations recommended by the manufacturer/in-house facility. After incubation for 10 minutes at $4^{\circ} \mathrm{C}$, the cells were washed using PBS+3\%FCS, and resuspended in PBS $+3 \% \mathrm{FCS}$ with the addition of propidium iodide as a viability marker. Flow cytometric analyses were performed on either a FACS Calibur or LSRII (BD Biosciences) and data files were analyzed with FlowJo software (Tree Star). Viable cells were gated using forward/side scatter and exclusion of propidium iodide-positive cells.

\subsection{Proliferation Assays}

For antigen-induced proliferation, $2.5 \times 10^{4} 2.10 \mathrm{~T}$ cells were cultured with 5 $\mu \mathrm{g} / \mathrm{ml} \mathrm{OVA}^{143-157}$ peptide (Canpeptide), and $5 \times 10^{5}$ irradiated splenocytes isolated from 6 - 10 week old C57BL/6 mice (Jackson Laboratories) in 96-well (Corning Costar) plates. For mAb-mediated proliferation, $2 \times 10^{4} 2.10 \mathrm{~T}$ cells, or $4 \times 10^{4}$ primary $\mathrm{T}$ cells were cultured in 96 -well plates pre-coated overnight at $4^{\circ} \mathrm{C}$ with the indicated concentrations of anti-TCRC $\beta$ or anti-CD3e. Triplicate cultures were pulsed with $1 \mu \mathrm{Ci}{ }^{3} \mathrm{H}-\mathrm{TdR}$, harvested 6 hours later on Unifilter plates (PerkinElmer), and thymidine uptake was assessed using a TopCount 
NXT $^{\mathrm{TM}}$ Microplate Scintillation and Luminescence Counter (Packard).

\subsection{IL-2 ELISA}

IL-2 concentrations in culture supernatants were determined using a mouse IL-2-specific ELISA kit (eBioscience) according to the manufacturer's protocol. Absorbances at 450 and $570 \mathrm{~nm}$ were read using the BioTek Eon spectrophotometer and the BioTek Gen5 software and IL-2 concentrations determined.

\subsection{Quantification of IL-2 mRNA by Digital Droplet PCR (ddPCR)}

$2 \times 10^{4} \mathrm{GPI}^{+/-} 2.10$ variants or $4 \times 10^{4}$ primary $\mathrm{CD}^{+} \mathrm{GPI}^{+-} \mathrm{T}$ cells were stimulated in 96 well plates precoated with either $9 \mu \mathrm{g} / \mathrm{ml}$ of anti-TCRC $\beta$ for the clonal variants or $3 \mu \mathrm{g} / \mathrm{ml}$ of anti-CD3 $\varepsilon$ for primary $\mathrm{T}$ cells. At the indicated time points, 12 replicate wells of each of the four populations were harvested and lysed in Tri Reagent (Sigma Aldrich) according to the manufacturer's protocol. The RNA was extracted, quantified and assessed for purity using a NanoDrop spectrophotometer or a Qubit 3 Fluorometer (Thermo Scientific). 0.5 - $1 \mu \mathrm{g}$ of RNA was used to prepare cDNA using reagents and protocol from Life Technologies. The ddPCR was performed in a $20 \mu \mathrm{l}$ volume containing cDNA template derived from $10 \mathrm{ng}$ of RNA in RNase/DNase-free water, $100 \mathrm{nM}$ each of forward (AACCTGAAACTCCCCAGGAT) and reverse

(CGCAGAGGTCCAAGTTCAT) IL-2 primers and $10 \mu \mathrm{l}$ of $2 \times$ QX200 ddPCR EvaGreen supermix (Bio-Rad). The assay mixtures were loaded into a disposable droplet generator cartridge (Bio-Rad), followed by the addition of $70 \mu \mathrm{l}$ of droplet generation oil (Bio-Rad) into each of the eight oil wells. The cartridge was then placed inside the QX200 droplet generator (Bio-Rad). When droplet generation was completed, the droplets were transferred to a 96-well PCR plate (Eppendorf) using a multichannel pipette. The plate was heat-sealed with foil using the PX1 PCR Plate Sealer and placed in C1000 Touch Thermal Cycler (Bio-Rad). Thermal cycling conditions were as follows: $95^{\circ} \mathrm{C}$ for 5 minutes, then 44 cycles of $95^{\circ} \mathrm{C}$ for 30 seconds and $60^{\circ} \mathrm{C}$ for 1 minute, and $4^{\circ} \mathrm{C}$ for 5 minutes, $90^{\circ} \mathrm{C}$ for 5 minutes, and a $4^{\circ} \mathrm{C}$ indefinite hold. EvaGreen fluorescent signal, labelling the IL-2 RNA sequence in each droplet was counted by QX200 digital droplet reader and analyzed by QuantaSoft analysis software ver.1.7.4.0917 (Bio-Rad).

\subsection{PD-1/PD-L1-Fc Inhibition Assays}

The mAb S4B6 renders IL-2 incapable of binding its high affinity receptor, $\mathrm{CD} 25$, thereby antagonizing IL-2 cellular function. When added at $1 \mu \mathrm{g} / \mathrm{ml}$ in cultures of anti-CD3e stimulated $\mathrm{GPI}^{-}$variants, the level of functional IL-2 measured by ELISA in these supernatants was reduced approximately to the level observed in $\mathrm{GPI}^{+}$cultures (data not shown). Note that the IL-2 ELISA kit from eBioscience uses a capture antibody that binds both IL-2 and IL-2-S4B6complexes whereas the detection antibody reveals only free IL-2 [20], enabling 
the empirical estimate of the required amount S4B6 to neutralize IL-2 concentrations in $\mathrm{GPI}^{-}$culture supernatants such that they match those in $\mathrm{GPI}^{+}$culture supernatants.

$2 \times 10^{4}$ clonal T cells or $4 \times 10^{4}$ primary T cells were seeded per well, in tripli-

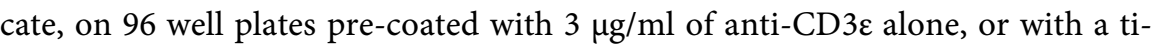
tration of PD-L1-Fc or its isotype control. When indicated, S4B6 or its isotype control, rat IgG2a, was added at $1 \mu \mathrm{g} / \mathrm{ml}$ to all cultures containing PD-L1-Fc or PD-L1. HIS or their respective controls. Cultures were pulsed with $1 \mu \mathrm{Ci}{ }^{3} \mathrm{H}-\mathrm{TdR}$ at the indicated time points, harvested 6 hours later on Unifilter plates (PerkinElmer) and thymidine uptake was assessed by scintillation spectroscopy. The inhibitory effect of PD-L1-Fc or PD-L1.HIS is presented as \% control: the ratio of cpm from cultures containing anti-CD3ع plus PD-L1-Fc, PD-L1.HIS or their respective controls versus those containing anti-CD3 $\varepsilon$ alone, which was set to $100 \%$.

\subsection{Statistical Analysis}

Results represent the mean \pm standard error calculated based on triplicate cultures from representative experiments. Experiments were repeated a minimum of 3 times. $\mathrm{P}$ values among experimental groups were determined by the unpaired Student's t-test.

\section{Results and Discussion}

\subsection{Enhanced IL-2 Production and Signalling Sequelae Imparted by GPI-AP Deficiency}

The initial observation supporting a role for GPI-AP in the regulation of T cell activation and growth was established in GPI-AP deficient variants of the IL-2-dependent, $\mathrm{CD}^{-}$, I- $\mathrm{A}^{\mathrm{b}}$ restricted, $\mathrm{OVA}^{143-157}$ specific, T cell clone 2.10 [18]. The deficiency in the $2.10 \mathrm{GPI}^{-}$variants is due to an autosomal mutation within a gene encoding one of seven components of the transferase complex termed Pigp [21]. The functional transferase complex predicates the initial step in GPI biosynthesis. The establishment of stable infectants of 2.10 GPI-AP $^{-}$ variants demonstrates the causal role of Pigp deficiency (Figure 1). Insight was derived from the differential kinetics of response of $2.10 \mathrm{GPI}^{+/-}$variants to antigen.

While both the GPI-AP ${ }^{+}$and GPI-AP ${ }^{-} 2.10$ clonal variants exhibit comparable initial responses, GPI-AP ${ }^{-}$variants exhibit prolonged ${ }^{3} \mathrm{H}-\mathrm{TdR}$ uptake, which was reversed with the rescue of GPI-AP expression mediated by Pigp infection (Figure 1(B)). The potential role of antigen presenting cells in supporting differential responsiveness was excluded by assessing the responses of 2.10 GPI-AP ${ }^{+/-}$variants to plate bound anti-TCRC $\beta$ which reveals that the differential kinetics of responsiveness to TCR ligation in GPI-AP ${ }^{+/-}$variants is cell intrinsic (Figure 1(C)).

2.10 clonal variants are IL-2 dependent, and cell death in the absence of IL-2 
A
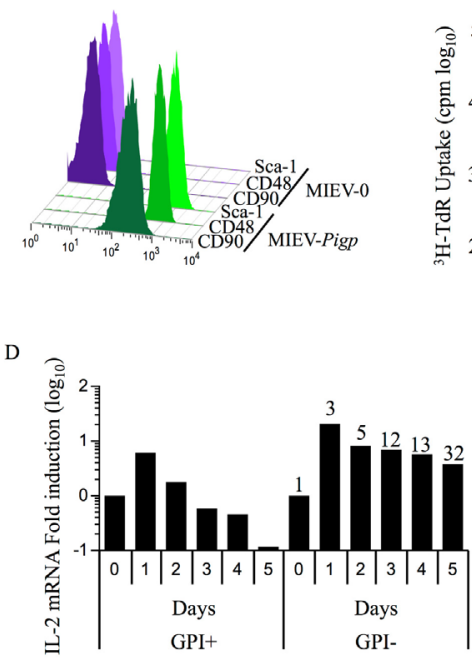

$\mathrm{F}$
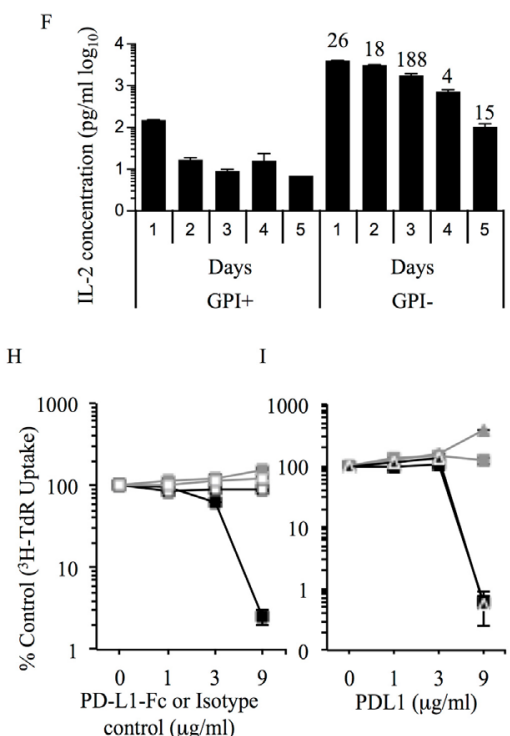

B

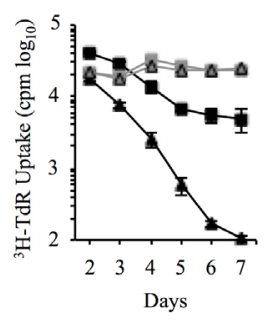

C

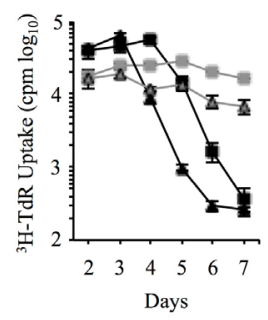

G
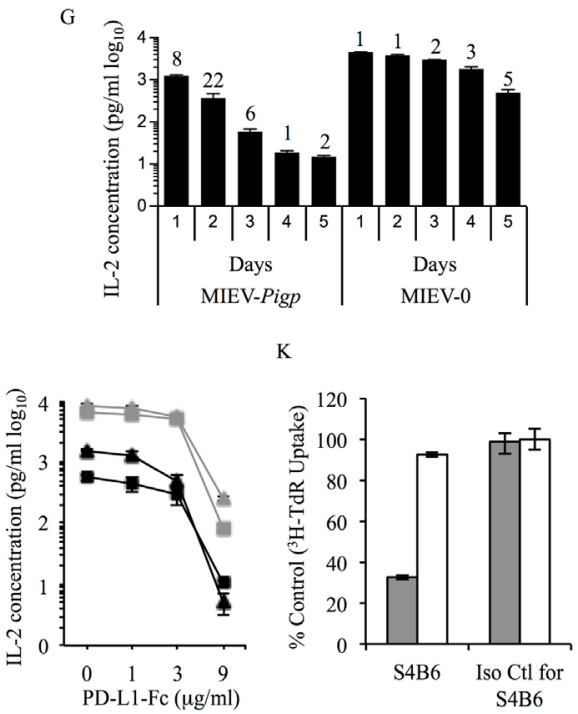

Figure 1. Characterization of a new GPI-AP deficient variant. (A). Ectopic expression of Pigp rescues Sca-1, CD48, and CD90 expression in the MIEV-Pigp infected variant of 2.10, while the empty vector (MIEV-0) infectant remains GPI-AP deficient. (B)-(C). Parental $2.10 \mathrm{GPI}^{+}$(black squares), $\mathrm{GPI}^{-}$variants (grey squares), infected $\mathrm{GPI}^{-}$-MIEV-0 (grey triangles), and GPI--MIEV-Pigp (black triangles) $2.10 \mathrm{~T}$ cells were cultured with $5 \mu \mathrm{g} / \mathrm{ml} \mathrm{OVA}^{143-157}$ peptide and $5 \times 10^{5}$ irradiated splenocytes (B) or in wells precoated with $9 \mu \mathrm{g} / \mathrm{ml}$ anti-TCRC $\beta \mathrm{mAb}(\mathrm{C})$. At each of the indicated time points, triplicate cultures were pulsed with $1 \mu \mathrm{Ci}{ }^{3} \mathrm{H}-\mathrm{TdR}$, harvested 6 hours later and ${ }^{3} \mathrm{H}$-TdR uptake was assessed by liquid scintillation spectroscopy. (D)-(E). IL-2 mRNA fold induction was assessed in $\mathrm{GPI}^{+}, \mathrm{GPI}^{-}, \mathrm{MIEV}-$ Pigp and MIEV-0 clonal variants stimulated on plates precoated with $9 \mu \mathrm{g} / \mathrm{ml}$ anti-TCRC $\beta$ and harvested at the indicated time points, day 0 represents IL-2 mRNA levels contained in cells immediately upon harvest from IL-2 containing growth cultures. In (D), the ratio of IL-2 mRNA fold induction between $\mathrm{GPI}^{-}$and $\mathrm{GPI}^{+}$cells is indicated above each time point. The mean \pm standard error of the peak anti-TCRC $\beta$ induced fold-increment of mRNA from GPI-AP ${ }^{-}$variants in 3 independent experiments is $18 \pm 8$-fold. In (E), the number above each time point represents the ratio of IL-2 mRNA fold induction between MIEV-Pigp infectants and GPI ${ }^{+}$cells, or between MIEV-0 infectants and GPI- cells. 
Ratios were rounded to the nearest whole number. The means \pm standard errors of anti-TCRC $\beta$ induced IL-2 mRNA from Pigp infectants in 3 independent experiments inclusive of the representative experiment ranged from 3-5 $\pm 1-2$ at days $1-3$ and $9-51 \pm 2-24$ at days 4 and 5 respectively. And the means and standard errors of anti-TCRC $\beta$ induced IL- 2 mRNA levels from MIEV-0 infectants, in three independent experiments, ranged from 1-2 \pm 0.01-0.3 over the five-day time course. (F)-(G). The supernatants from cultures of $\mathrm{GPI}^{+}, \mathrm{GPI}^{-}$, MIEV-Pigp and MIEV-0 clonal variants stimulated on plates precoated with $9 \mu \mathrm{g} / \mathrm{ml}$ of anti-TCRC $\beta$ were collected at the indicated time points, and IL-2 concentration was assessed by ELISA. In (F), the number over each of the time points of $\mathrm{GPI}^{-}$cells represents the ratio of $\mathrm{GPI}^{-} / \mathrm{GPI}^{+} \mathrm{IL}-2$ concentrations. The mean \pm standard error of the peak anti-TCRC $\beta$ induced fold-increment of IL-2 levels from GPI-AP ${ }^{-}$variants in 5 independent experiments is $181 \pm 26$-fold. In (G), the number over each of the time points of MIEV-Pigp cells represents the ratio of MIEV-Pigp/GPI IL-2 concentrations; and number over each of the MIEV-0 time points represents the ratio of $\mathrm{MIEV}-0 / \mathrm{GPI}^{-} \mathrm{IL}-2$ concentrations. Ratios were rounded to the nearest whole number. The means \pm standard errors of anti-TCRC $\beta$ induced IL-2 from Pigp infectants in 3 independent experiments ranged from 3-10 \pm 1-6 over the 5-day time course. And the mean and standard error of anti-TCRC $\beta$ induced IL-2 levels from MIEV-0 infectants ranged from 1-6 \pm 0.01-1 over the five-day time course. $(\mathrm{H})$. Cultures of $2.10 \mathrm{GPI}^{+}$(black) and $\mathrm{GPI}^{-}$(grey) variants were stimulated on plates precoated with $3 \mu \mathrm{g} / \mathrm{ml}$ anti-CD3e alone, or with a titration of PD-L1-Fc (closed squares) or its isotype control (open squares). Cultures were pulsed with $1 \mu \mathrm{Ci}{ }^{3} \mathrm{H}-\mathrm{TdR}$ at 20 hours, harvested 6 hours later and thymidine uptake assessed by liquid scintillation spectroscopy. Percent control was calculated using the ratio of cpm in cultures stimulated with anti-CD3e plus PD-L1-Fc or isotype control divided by cpm of cultures stimulated with anti-CD3 $\varepsilon$ alone, set to $100 \%$. (I). GPI ${ }^{+}$(black squares) and $\mathrm{GPI}^{-}$ (grey squares) variants, MIEV-0 infectants of GPI- (grey triangles) and MIEV-Pigp infectants of $\mathrm{GPI}^{-}$(black triangles with white outline) infected cells were stimulated on plates precoated with $3 \mu \mathrm{g} / \mathrm{ml}$ anti-CD $3 \varepsilon$ alone or with a titration of PD-L1-Fc. Cultures were pulsed with $1 \mu \mathrm{g} / \mathrm{ml}$ of ${ }^{3} \mathrm{H}-\mathrm{TdR}$ at 20 hours, harvested 6 hours later, and ${ }^{3} \mathrm{H}-\mathrm{TdR}$ uptake assessed by liquid scintillation spectroscopy. Percent control was determined as in H. J. GPI ${ }^{+}$(black squares) and $\mathrm{GPI}^{-}$(grey squares) variants, MIEV-0 infectants of $\mathrm{GPI}^{-}$(grey triangles) and MIEV-Pigp infectants of $\mathrm{GPI}^{-}$(black triangles) were stimulated on plates precoated with $3 \mu \mathrm{g} / \mathrm{ml}$ anti-CD3$\varepsilon$ alone or with a titration of PD-L1-Fc for $24 \mathrm{hrs}$ and IL-2 concentrations in supernatants of cultures were determined by ELISA. (K). $2.10 \mathrm{GPI}^{-}$cells were stimulated on plates precoated with 3 $\mu \mathrm{g} / \mathrm{ml}$ of anti-CD3 $\varepsilon$ and either $20 \mu \mathrm{g} / \mathrm{ml}$ of PD-L1.HIS (grey bars) or CEA-N.HIS as control (white bars). Cultures were supplemented with $1 \mu \mathrm{g} / \mathrm{ml} \mathrm{mAb}$ S4B6 (left bars), such that levels of IL-2 present in the culture supernatants approximated those generated by $\mathrm{GPI}^{+}$parental variant, or with $1 \mu \mathrm{g} / \mathrm{ml}$ of S4B6 isotype control (right bars). Cultures were pulsed with $1 \mu \mathrm{g} / \mathrm{ml}{ }^{3} \mathrm{H}$-TdR at 20 hours, harvested 6 hours later, and ${ }^{3} \mathrm{H}$-TdR uptake assessed by liquid scintillation spectroscopy. Inhibition by PD-L1.HIS or its control in the presence of S4B6 or its isotype control is presented as \% control as in $\mathrm{H}$ above.

ensues through the intrinsic apoptotic pathway [22] [23]. Sustained growth of 2.10 is maintained through either the addition of exogenous IL-2, or TCR-induced production of endogenous IL-2. The differential responses of $\mathrm{GPI}^{-\mathrm{AP}^{+/-}} 2.10$ variants to TCR ligation is not due to impaired function of IL-2R (Figure 2(A) and Figure 2(B)), rather, to differential anti-TCR induced de novo IL-2 mRNA and protein synthesis. While the kinetics of IL-2 mRNA induction 
A

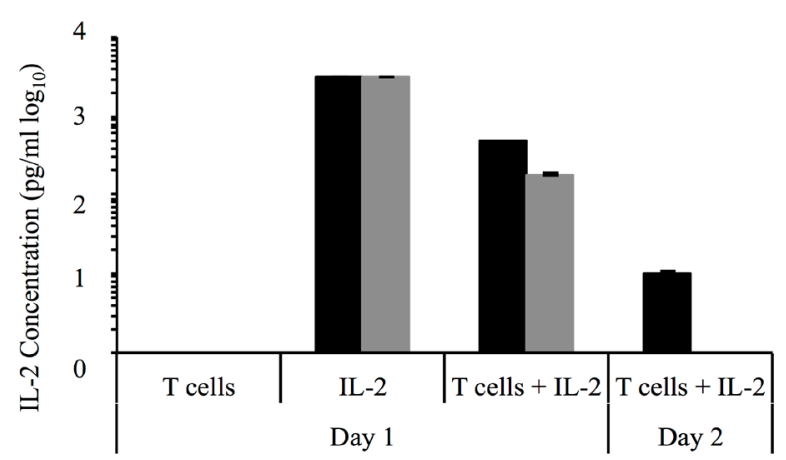

B

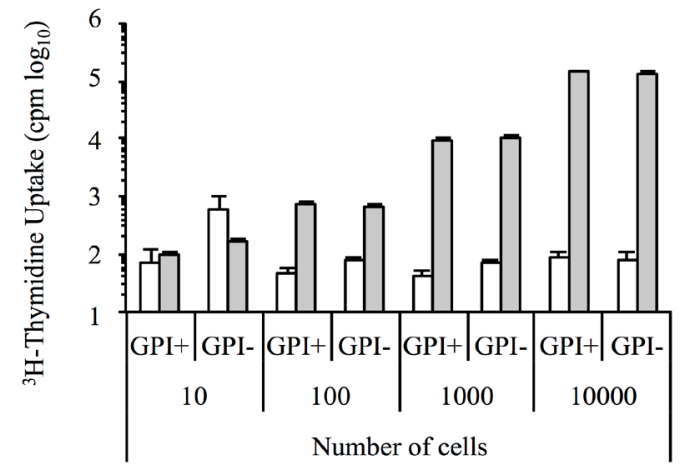

C

GPI+
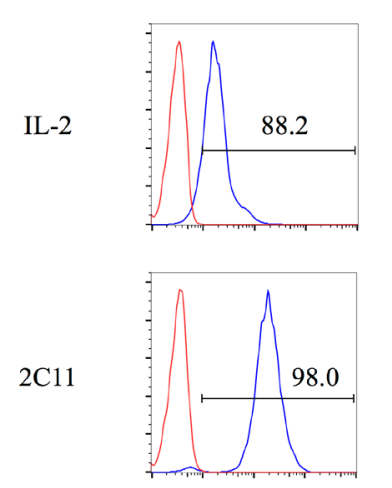

PD-1
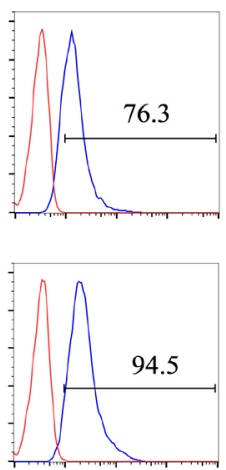

PD-L1
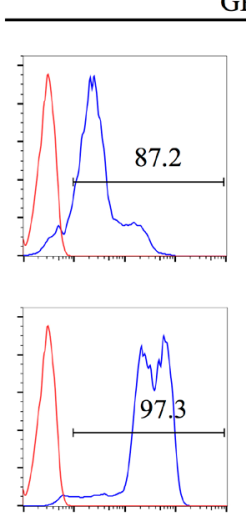

PD-1 GPI-
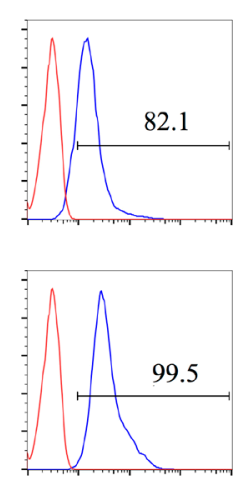

PD-L1

Figure 2. Functional IL-2R and comparable levels of PD-1 and PD-L1 on GPI ${ }^{+}$and $\mathrm{GPI}^{-}$variants of clone 2.10 cells. (A). $2 \times 10^{4} \mathrm{GPI}^{+}$(black bars) or $\mathrm{GPI}^{-}$(grey bars) $2.10 \mathrm{~T}$ cells were added, or not, in wells containing media alone or supplemented with $3 \mathrm{ng} / \mathrm{ml}$ of recombinant murine IL-2. Supernatants were collected at the indicated time points and IL-2 concentrations determined by ELISA. (B). Varying numbers of $\mathrm{GPI}^{+}$and $\mathrm{GPI}^{-} 2.10 \mathrm{~T}$ cells were cultured in medium alone (white bars) or medium supplemented with $3 \mathrm{ng} / \mathrm{ml}$ of recombinant murine IL-2 (grey bars). Cultures were pulsed with $1 \mu \mathrm{g} / \mathrm{ml}^{3} \mathrm{H}$-TdR at 48 hours, harvested 6 hours later, and ${ }^{3} \mathrm{H}$-TdR uptake assessed using liquid scintillation spectroscopy. (C). GPI ${ }^{+}$and $\mathrm{GPI}^{-}$variants were cultured in $3 \mathrm{ng} / \mathrm{ml}$ of recombinant murine IL-2 or stimulated on plates precoated with 3 $\mu \mathrm{g} / \mathrm{ml}$ of anti-CD3e. Cells were harvested at 20 hours and stained for expression of PD-1 and PD-L1 and analysed flow cytometrically. PD-1 or PD-L1 staining versus isotype control staining is illustrated with blue and red lines, respectively. 
in GPI-AP ${ }^{+/-}$variants is comparable, the fold induction of IL-2 mRNA is significantly higher in the GPI stimulated cells at each time point assayed. Specifically, the peak of anti-TCRC $\beta$ induced IL- 2 mRNA induction is at day 1 for both $\mathrm{GPI}^{-\mathrm{AP}^{+/-}}$variants, but 3.4-fold higher in GPI-AP ${ }^{-}$variants. The levels of IL-2 mRNA in GPI-AP ${ }^{+/-}$variants declined in parallel with their respective ${ }^{3} \mathrm{H}-\mathrm{TdR}$ uptake responses, but levels of IL-2 mRNA remain up to 30-fold higher in GPI-AP ${ }^{-}$variants over the time course assessed (Figure $1(D)$ ). The role of GPI-AP in the regulation of anti-TCRC $\beta$ induced IL-2 mRNA is formally demonstrated using Pigp infectants of $2.10 \mathrm{GPI}^{-\mathrm{AP}^{-}}$variants (Figure 1(E)). Specifically, anti-TCRC $\beta$ induced IL-2 mRNA in Pigp infectants approach levels observed in GPI- $\mathrm{AP}^{+}$variants assessed at the earliest time points but consistently rose to levels approaching GPI-AP ${ }^{-}$variants at the later time points (Figure 1(E)) which, notwithstanding, did not translate into increased levels of IL-2 detected in culture supernatants (Figure $1(\mathrm{~F})$ ), as will be discussed below. Levels of anti-TCRC $\beta$ induced IL-2 mRNA in MIEV-0 infectants remain within 2-fold of those observed in GPI-AP ${ }^{-}$variants (Figure $1(\mathrm{G})$ ).

The enhanced and prolonged anti-TCRC $\beta$ induced IL- 2 mRNA production in $\mathrm{GPI}^{-\mathrm{AP}^{-}}$variants correlates with enhanced amounts of IL-2 detected in culture supernatants of the same cell populations over the time course tested. While levels of IL-2 in supernatants of both $\mathrm{GPI}^{+/-}$variants declined over time, supernatants of GPI-AP ${ }^{-}$variants contained from 15-188-fold more IL-2 than those from GPI- $\mathrm{AP}^{+}$variants at the same time points (Figure $1(\mathrm{~F})$ ). And further, as observed for increases in mRNA induction, IL-2 levels in supernatants of anti-TCRC $\beta$ stimulated Pigp infectants of GPI-AP ${ }^{-}$variants approach levels observed in GPI- $\mathrm{AP}^{+}$variants, with greater effect at later time points (Figure $1(G)$ ). Levels of IL-2 in culture supernatants in MIEV-0 infectants remain either identical to those observed in GPI-AP ${ }^{-}$variants, or enhanced 2-5-fold (Figure $1(\mathrm{G})$ ).

Convergent evidence for the role of GPI-AP in regulating TCR induced IL-2 production derives from the analysis of the differential effects of PD1 mediated inhibition of TCR signalling in GPI-AP ${ }^{+/}$variants. PD1-mediated effects are mitigated by exogenous IL-2. Specifically, the exogenous IL-2 sensitive sequelae induced upon PD1 ligation [24] include attenuation of TCR-mediated clonal expansion [16] and dramatic decreases in IL-2 production [25].

PD1, and its agonistic ligand, PD-L1 are expressed at comparable levels on both GPI-AP ${ }^{+/-}$variants propagated in IL-2 (Figure 2(C)). Further, PD1 expression is materially upregulated and PD-L1 less so, upon anti-CD3E stimulation in both GPI-AP ${ }^{+/-}$variants (Figure $2(\mathrm{C})$ ).

PD1/PD-L1-mediated attenuation of TCR signalling was assessed by stimu-

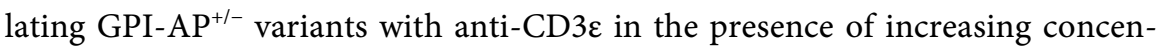
trations of PD-L1-Fc using a recombinant human B7-H1/PD-L1-Fc chimera [16]. Increasing concentrations of PD-L1-Fc suppress anti-CD3E induced ${ }^{3} \mathrm{H}-\mathrm{TdR}$ uptake by the GPI-AP ${ }^{+}$clonal variants, exclusively (Figure $1(\mathrm{H})$ ). The 
formal demonstration of the role of GPI-AP in mediating this differential inhibition is demonstrated by rescuing PD-L1-mediated inhibition of anti-CD3 $\varepsilon$ induced DNA synthesis in GPI-AP ${ }^{-}$Pigp infectants (Figure 1(I)).

However, as illustrated in Figure 1(J), the efficacy of PD1 mediated inhibition of IL-2 concentrations in culture supernatants of anti-CD3 $\varepsilon$ stimulated GPI-AP ${ }^{+/}$ variants is comparable, ranging from 50-100-fold. This reveals the potential molecular basis of differential PD-LI-Fc mediated inhibition of induced ${ }^{3} \mathrm{H}-\mathrm{TdR}$ uptake in $\mathrm{GPI}^{+}$and $\mathrm{GPI}^{-}$clonal variants.

Specifically, the amount of IL-2 detected in culture supernatants of GPI-AP ${ }^{-}$ variants stimulated with anti-CD3e and $9 \mu \mathrm{g} / \mathrm{ml}$ of PD-L1-Fc, while reduced 30-80-fold relative to controls, was on average 10-50-fold higher compared to levels observed in supernatants of $\mathrm{GPI}^{+}$variants stimulated in the same conditions. Thus, while the fold reduction of IL-2 detected is comparable in the GPI-AP sufficient and deficient variants (Figure $1(J)$ ), the higher concentration of IL-2 in culture supernatants of GPI-AP ${ }^{-}$variants may be sufficient to mitigate the inhibitory effects of PD1 ligation. The prediction follows that reduction of available IL-2 in culture supernatants of anti-CD3e stimulated $\mathrm{GPI}^{-}$clonal variants will render them susceptible to PD-L1-Fc mediated inhibition. This was tested through the addition of an IL-2 neutralizing mAb to reduce levels of IL-2

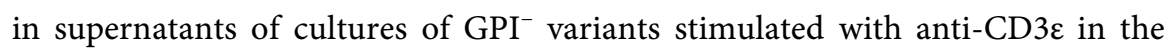
presence of $9 \mu \mathrm{g} / \mathrm{ml}$ of PD-L1-Fc, to those approximating IL-2 levels observed in the supernatants of the $\mathrm{GPI}^{+}$variants stimulated in the same conditions. As illustrated in Figure 1(K), addition of neutralizing anti-IL-2, but not isotype control, rescued $70 \%$ inhibition of the anti-CD3 $\varepsilon$ induced response of $\mathrm{GPI}^{-}$variants in a PD-L1 specific fashion.

Taken together these results support the conclusion that GPI-AP regulate TCR induced IL-2 production and posits their role in attenuating TCR signalling.

\subsection{The TCR Induced Signalling Sequelae Observed in GPI-AP- Clones Is Recapitulated in GPI-AP- Primary CD4+ T Cells}

Initial results assessing TCR signalling in GPI-AP deficient primary T cells are mixed. The conditional disruption of the Piga gene that encodes one of the seven components of the tranferase complex predicating the initial step in GPI-anchor biosynthesis revealed no significant impact on TCR signalling [19]. However, subsequent analyses of splenocytes from these animals revealed a 2-3-fold enhanced responsiveness to mitogen, and a 3 -fold increased response of $\mathrm{CD}^{+} \mathrm{T}$ cells to allogeneic stimulation, both assessed by ${ }^{3} \mathrm{H}-\mathrm{TdR}$ uptake [26]. Further, the response of an OVA specific $\mathrm{T}$ cell clone derived from these mice to mitogen, but not to antigen, was enhanced 3-fold. Importantly this enhancement was reversed upon retroviral infection of the clone with Piga, restoring GPI-AP expression [26]. These results were based on ${ }^{3} \mathrm{H}-\mathrm{TdR}$ uptake, exclusively, notably IL-2 production was not measured. Here we reassess responsiveness of purified

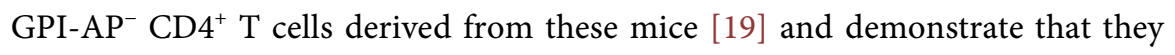


recapitulate the IL-2 phenotype observed in the GPI- $\mathrm{AP}^{-}$clonal variants.

As previously described, conditional disruption of Piga in these mice yields a $\mathrm{T}$ cell specific loss of GPI-AP expression, and enables the isolation of $>95 \%$ pure populations of $\mathrm{CD}^{+} \mathrm{GPI}-\mathrm{AP}^{-} \mathrm{T}$ cells (Figure $3(\mathrm{~A})$ ). Anti-CD3 $\varepsilon$ mediated stimulation of GPI-AP ${ }^{-}$cells results in a 3-7.5 -fold enhancement in ${ }^{3} \mathrm{H}-\mathrm{TdR}$ uptake compared to $\mathrm{CD} 4^{+} \mathrm{GPI}-\mathrm{AP}^{+}$control $\mathrm{T}$ cells, over the time course assessed (Figure 3(B)). In contrast to the precipitous waning of the anti-TCRC $\beta$ induced stimulation of the IL-2-dependent GPI-AP ${ }^{+}$clonal variants (Figure $1(\mathrm{~B})$ and Figure $1(\mathrm{C})$ ), as expected the kinetics of anti-CD3 $\varepsilon$ induced ${ }^{3} \mathrm{H}-\mathrm{TdR}$ uptake in primary GPI-AP ${ }^{+/-} \mathrm{CD} 4^{+} \mathrm{T}$ cells is not materially exacerbated by IL-2-regulated apoptosis over the time course assessed (Figure 3(B)). Notwithstanding, the concordant observation is that differential TCR induced IL-2 mRNA and protein levels observed in cultures of $\mathrm{GPI}^{+/-}$primary $\mathrm{T}$ cells recapitulate those observed in the GPI-AP ${ }^{+/-}$clonal variants.

Specifically, levels of anti-CD3e induced IL- $2 \mathrm{mRNA}$ in GPI-AP ${ }^{-}$primary $\mathrm{T}$ cells range from 3-5-fold higher over the time course assayed (Figure 3(C)). This differential was paralleled by an increase in IL-2 concentrations in supernatants of the anti-CD3 $\varepsilon$ stimulated GPI-AP ${ }^{-} \mathrm{T}$ cells which are up to 20 -fold higher at peak (Figure 3(D)). Further, the IL-2-dependent differential susceptibility of GPI- $\mathrm{AP}^{+/-}$primary $\mathrm{CD} 4^{+} \mathrm{T}$ cells to $\mathrm{PD} 1$ mediated inhibition of anti-CD3 $\varepsilon$ induced ${ }^{3} \mathrm{H}-\mathrm{TdR}$ uptake recapitulated the observations in GPI-AP ${ }^{+/-}$ clonal variants.

Specifically, increasing concentrations of PD-L1-Fc inhibits ${ }^{3} \mathrm{H}-\mathrm{TdR}$ uptake by GPI- $\mathrm{AP}^{+} \mathrm{CD}^{+}$primary $\mathrm{T}$ cells from 10 to 150 -fold, at days 2 and 4 , respectively, while no inhibition was observed in $\mathrm{GPI}_{-} \mathrm{AP}^{-} \mathrm{CD} 4^{+}$primary $\mathrm{T}$ cells (Figure 4(A)). However, PD-L1-Fc did inhibit anti-CD3 $\varepsilon$ induced IL-2 concentrations observed in supernatants of both GPI- $\mathrm{AP}^{+/-}$primary $\mathrm{T}$ cells by at least 10 -fold at

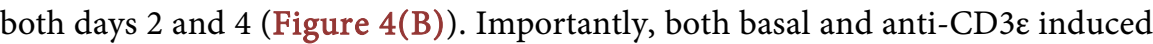
upregulated expression of $\mathrm{PD} 1$ and $\mathrm{PD}-\mathrm{L} 1$ levels are comparable in $\mathrm{GPI}-\mathrm{AP}^{+}$and GPI-AP ${ }^{-} \mathrm{CD}^{+}$primary $\mathrm{T}$ cells (Figure $4(\mathrm{C})$ ).

To determine whether the 20-100-fold higher concentrations of IL-2 in supernatants of anti-CD3e stimulated GPI-AP ${ }^{-}$primary $\mathrm{T}$ cells at days 2 and 4, respectively (Figure 4(B)), mitigate PD-L1-Fc-mediated inhibition, the impact of $\mathrm{mAb}$ mediated neutralization of IL-2 levels in supernatants of the GPI-AP ${ }^{-}$ $\mathrm{CD}^{+}$primary $\mathrm{T}$ cells to levels observed in supernatants of $\mathrm{GPI}-\mathrm{AP}^{+}$variants was assessed. As illustrated in Figure 4(D), mAb mediated neutralization of IL-2 rescues PD-L1-Fc mediated inhibition of anti-CD3e induced ${ }^{3} \mathrm{H}$-TdR uptake by $\mathrm{GPI}^{-\mathrm{AP}^{-}}$variants to $40 \%$ and $85 \%$ of control responses, at days 2 and 4 , respectively.

It is of note that analyses of $\mathrm{CD} 8^{+}$primary $\mathrm{T}$ cells did not follow suit. Specifi-

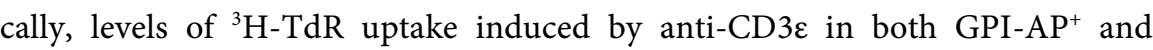
GPI-AP ${ }^{-} \mathrm{CD}^{+}$primary $\mathrm{T}$ cells was robust and comparable to those observed in GPI-AP ${ }^{+} \mathrm{CD} 4^{+}$primary $\mathrm{T}$ cells, over the same dose range of anti-CD3 $\varepsilon$ kinetics. However, levels attained by the GPI- $\mathrm{AP}^{+} \mathrm{CD}^{+}$were as high as or exceeded those 
A
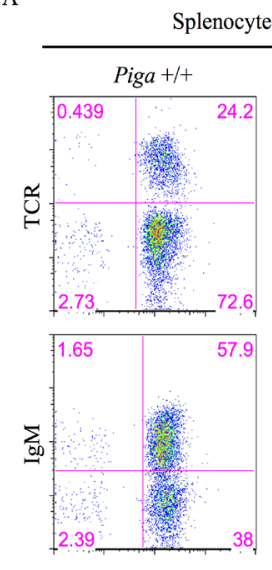

CD48
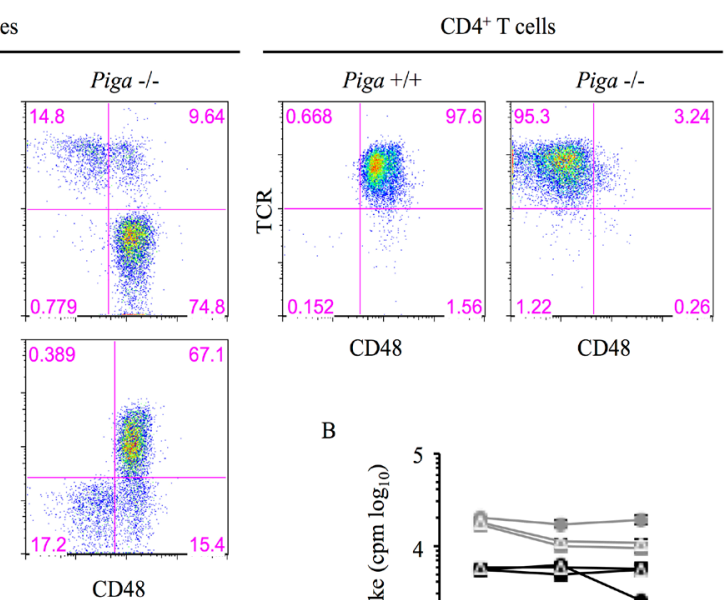

B

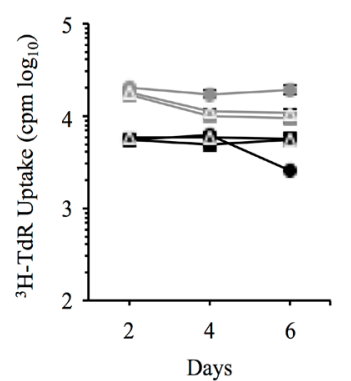

C
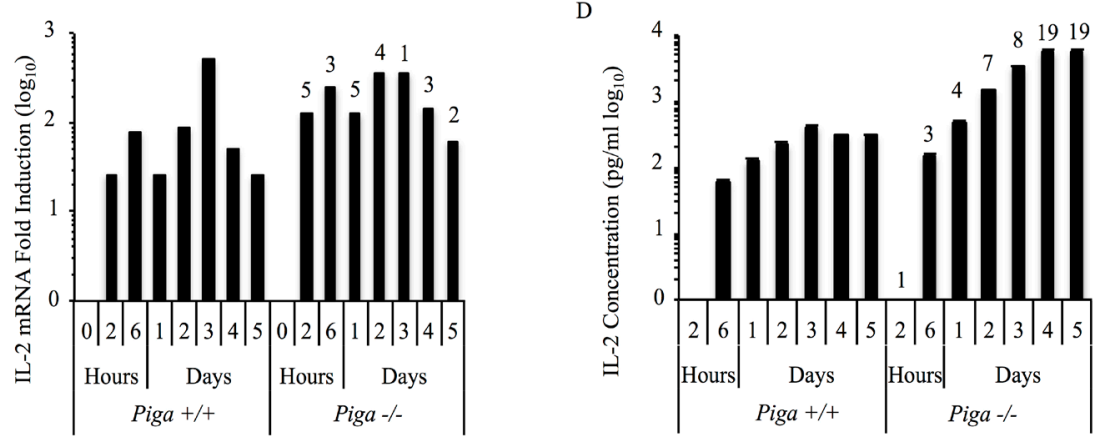

Figure 3. Conditional disruption of Piga in primary $\mathrm{CD}^{+} \mathrm{T}$ cells results in increased TCR-mediated IL-2 production. (A). FACS analyses of splenocytes and purified CD4 ${ }^{+} \mathrm{T}$ cells from $\mathrm{Piga}^{+/+}$and $\mathrm{Piga}^{-/-}$mice after staining for TCR and CD48. T cell specificity of Piga $^{-1-}$ deficiency is confirmed by assessing co-expression of IgM and CD48 on splenocytes. (B). Piga ${ }^{+/+}$(black) and $\mathrm{Piga}^{-/-}$(grey) $\mathrm{CD}^{+} \mathrm{T}$ cells were stimulated on plates precoated with 1 (circles), 3 (triangles), or 9 (squares) $\mu \mathrm{g} / \mathrm{ml}$ of anti-CD3ع Cultures were pulsed with $1 \mu \mathrm{g} / \mathrm{ml}$ of ${ }^{3} \mathrm{H}-\mathrm{TdR}$ at the indicated time points, harvested 6 hours later, and ${ }^{3} \mathrm{H}$-TdR uptake assessed by liquid scintillation spectroscopy. (C)-(D). Piga $^{+/+}$and Piga $^{-/-}$ $\mathrm{CD}^{+} \mathrm{T}$ cells were stimulated on plates precoated with $3 \mu \mathrm{g} / \mathrm{ml}$ of anti-CD3$\varepsilon$ and harvested at the indicated time points. IL- 2 mRNA fold induction was determined by ddPCR analysis (C) and IL-2 concentration was measured by ELISA (D). In (C), the ratio $\mathrm{GPI}^{-} / \mathrm{GPI}^{+}$of IL-2 mRNA fold induction is indicated above each of the $\mathrm{GPI}^{-}$time points; and in (D), the ratio of $\mathrm{GPI}^{-} / \mathrm{GPI}^{+} \mathrm{IL}-2$ concentrations is indicated above each of the $\mathrm{GPI}^{-}$ time points. Ratios were rounded to the closest whole number. The mean \pm standard error of the peak anti-CD3e induced fold-increment of mRNA from GPI-AP ${ }^{-} \mathrm{CD}^{+}$pri- $^{-}$ mary T cells in 3 independent experiments is $11 \pm 3$-fold. And the mean \pm standard error of the peak anti-CD3 $\varepsilon$ induced fold-increment of IL-2 levels from GPI-AP- $\mathrm{CD}^{+}$primary $\mathrm{T}$ cells in 7 independent experiments is $23 \pm 3$-fold.

observed in the GPI-AP- $\mathrm{CD}^{+}$populations. Further, levels of IL-2 observed in supernatants of both GPI-AP ${ }^{+}$and GPI-AP ${ }^{-}$cultures were below levels of detection (data not shown). 
A

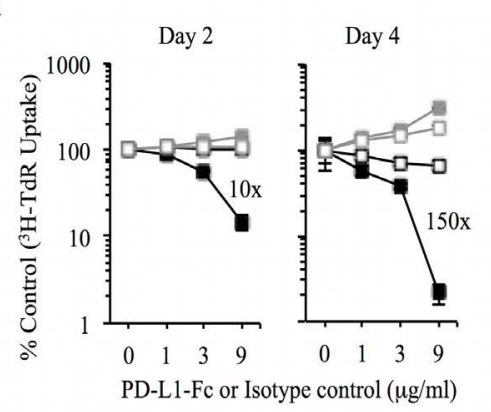

C

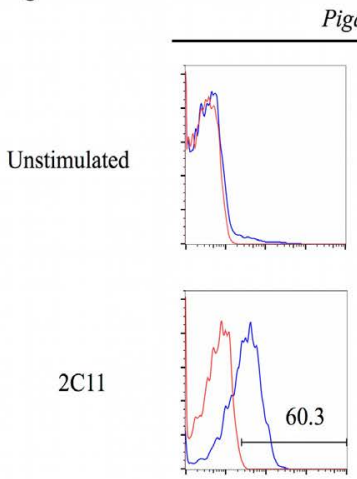

PD-1
Piga +1+
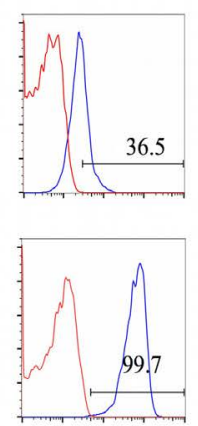

PD-L1
B
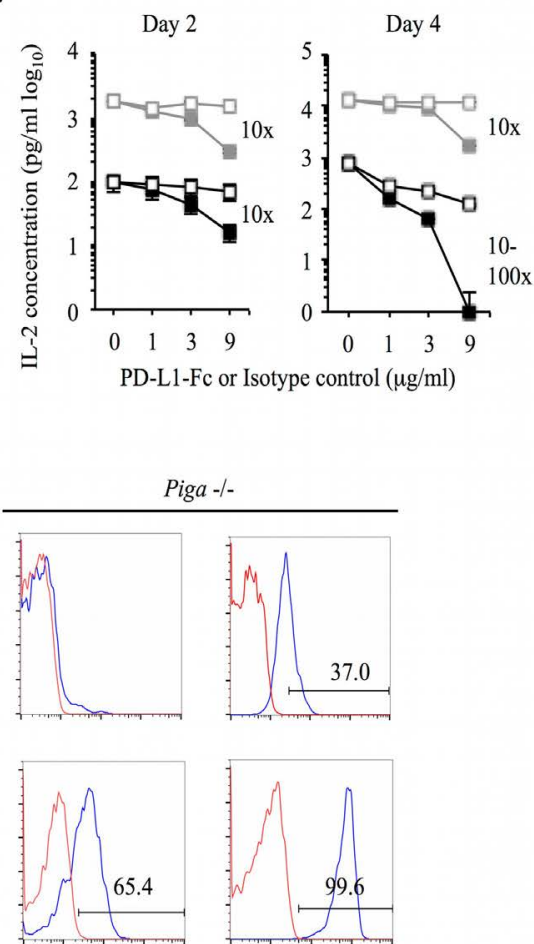

PD-1

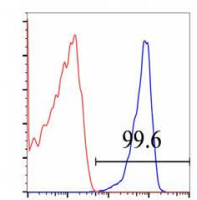

PD-L1

D

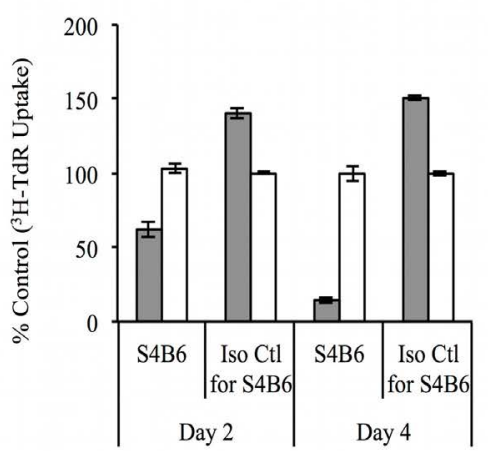

Figure 4. IL-2 mediated differential sensitivity to PD-L1 inhibition in GPI-AP-deficient primary $\mathrm{CD}^{+}{ }^{+} \mathrm{T}$ cells. (A). Piga ${ }^{+/+}$(black) and Piga $^{-/-}$(grey) $\mathrm{CD}^{+} \mathrm{T}$ cells were stimulated on plates precoated with $3 \mu \mathrm{g} / \mathrm{ml}$ of anti-CD3 $\varepsilon$ alone, or with a titration of PD-L1-Fc (closed squares) or its isotype control (open squares). Cultures were pulsed with $1 \mu \mathrm{g} / \mathrm{ml}$ ${ }^{3} \mathrm{H}$-TdR at the indicated time points, harvested 6 hours later, and ${ }^{3} \mathrm{H}-\mathrm{TdR}$ uptake assessed

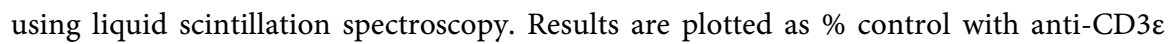
alone set at $100 \%$. (B). IL-2 concentrations were measured by ELISA in supernatants collected from cultures in (A). (C). PD-1 and PD-L1 expression levels were assessed by FACS on $\mathrm{Piga}^{+++}$and $\mathrm{Piga}^{-1-} \mathrm{CD}{ }^{+} \mathrm{T}$ cells ex vivo or stimulated for 20 hours on plates precoated with $3 \mu \mathrm{g} / \mathrm{ml}$ of anti-CD3e. Red line represents isotype control and blue line represents either PD-1 or PD-L1 staining. (D). CD4 ${ }^{+}$GPI-AP ${ }^{-} \mathrm{T}$ cells were cultured on plates precoated with $3 \mu \mathrm{g} / \mathrm{ml}$ of anti-CD3 $\varepsilon$ alone, or with $9 \mu \mathrm{g} / \mathrm{ml}$ of PD-L1-Fc (grey bars) or its isotype control (white bars) supplemented with $1 \mu \mathrm{g} / \mathrm{ml} \mathrm{S} 4 \mathrm{~B} 6$ or its isotype control. Cultures were pulsed at the indicated time points with $1 \mu \mathrm{g} / \mathrm{ml}{ }^{3} \mathrm{H}-\mathrm{TdR}$, harvested 6 hours later, and ${ }^{3} \mathrm{H}-\mathrm{TdR}$ uptake assessed using liquid scintillation spectroscopy. Inhibition mediated PD-L1-Fc or its isotype control is shown as \% control. 


\subsection{A Regulatory Role for the GPI-Anchor in TCR Induced IL-2 Production}

To address the potential differential role of GPI and GPI-AP in the attenuation of anti-CD3e induced IL-2 production, $\mathrm{GPI}^{+}$, GPI-AP ${ }^{-} \mathrm{CD}^{+}$primary $\mathrm{T}$ cells were generated. This was achieved through the conditional disruption of one of the five components that comprise the transamidase complex within the GPI-biosynthetic pathway, which mediates the transfer of protein containing the appropriate C-terminal signal sequence, to a mature GPI-anchor [27]. The conditional disruption of the Pigu gene was selected for this purpose as floxed-Pigu containing embryos were available at the European Mouse Mutant Archive (EMMA) Repository (Figure 5(A)). Embryos heterozygous for floxed exon 2 of Pigu, were implanted into pseudo pregnant females and offspring were bred and rearedin the specific pathogen free environment at the Sunnybrook Research Institute for preparation of the conditional Pigu deficient strain.

A breeding program analogous to that employed for the generation and maintenance of the Piga conditional mutants was implemented [19] with the specific modification to accommodate the fact that Pigu is autosomal. Specifically, floxed-Pigu heterozygous mice were bred with mice transgenic for Cre recombinase under the control of the proximal $L c k$ promoter ( $L c k$-Cre). As for the generation of Piga deficient peripheral T cells, the switch of $L c k$ promoters from the predominate use of the proximal promoter intra-thymically to the predominate use of the distal promoter in peripheral $\mathrm{T}$ cells [28], ensures not only that $\mathrm{T}$ cells emigrating from the thymus are Pigu deficient, it also safeguards against unwanted Cre-expression in peripheral $\mathrm{T}$ cells of these animals. The $\mathrm{F}_{1}$ progeny $\left[\right.$ Lck-Cre/Pigu $\left.u^{f o x}\right]$ were then intercrossed yielding some $\mathrm{F}_{2} L c k$-Cre/Pigu fox mice bearing the disruption of Pigu on both alleles. The expression of Pigu in progeny tail clippings, $\mathrm{B}$ cells and $\mathrm{T}$ cells demonstrates the selective absence of Pigu exon-2 in T cells, exclusively (Figure 5(B)). Flow cytometric analyses of splenocytes from Pigu deficient animals confirm the presence of GPI-AP deficient cells in a $\mathrm{T}$ cell specific fashion, and enabled the isolation of $>95 \%$ pure populations of Pigu deficient, GPI-AP ${ }^{-}, \mathrm{CD}^{+}$primary T cells (Figure $5(\mathrm{C})$ ).

Formal proof that mature GPI-anchor expression is retained on Pigu deficient $\mathrm{CD} 4^{+} \mathrm{T}$ cells is demonstrated by staining with a mAb specific for unlinked GPIs expressing an $\mathrm{N}$-acetylgalactosamine side chain [15] [29]. As expected, this $\mathrm{mAb}$ does not stain $\mathrm{CD}^{+}$primary $\mathrm{T}$ cells from either Piga or Pigu sufficient $\mathrm{CD} 4^{+} \mathrm{T}$ cells, as the side chain is blocked through the addition of GPI-associated proteins; nor does it stain Piga-deficient $\mathrm{CD} 4^{+} \mathrm{T}$ cells, which lack both the GPI-anchor and therefore GPI-AP (Figure 5(D)). Only Pigu deficient CD4 ${ }^{+} \mathrm{T}$ cells express the ligand for the $\mathrm{T} 5 \mathrm{mAb}$, and staining is in the majority PI-PLC sensitive, confirming the GPI-linkage (Figure 5(D)).

Comparative assessment of anti-CD3 $\varepsilon$ induced ${ }^{3} \mathrm{H}-\mathrm{TdR}$ uptake, induction of IL-2 specific mRNA and levels of IL-2 in culture supernatants of $\mathrm{Pigu}^{+/+}$and $\mathrm{Pigu}^{-/-}$primary $\mathrm{CD}^{+} \mathrm{T}$ cells demonstrates fundamental differences in the 
A

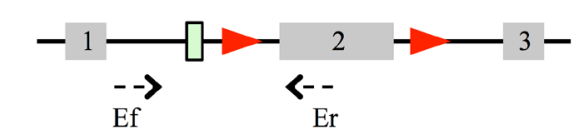

$\mathrm{C}$
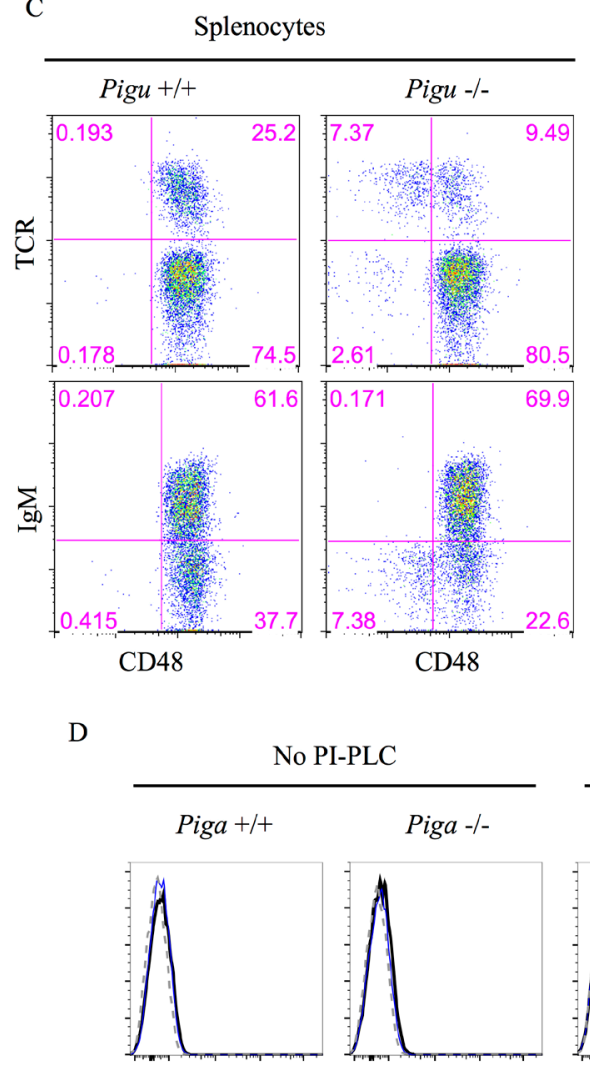

No PI-PLC

Pigu $+/+$

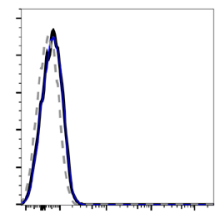

AF 488

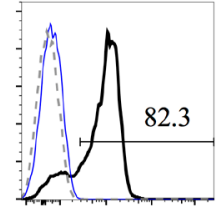

B

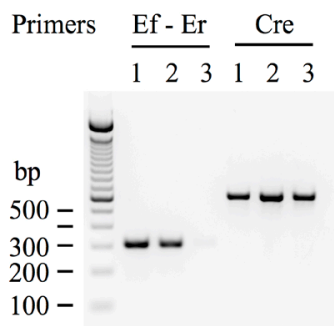

$\mathrm{CD}^{+} \mathrm{T}$ cells

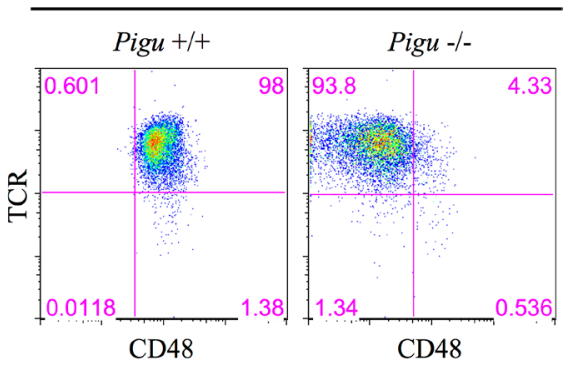

PI-PLC

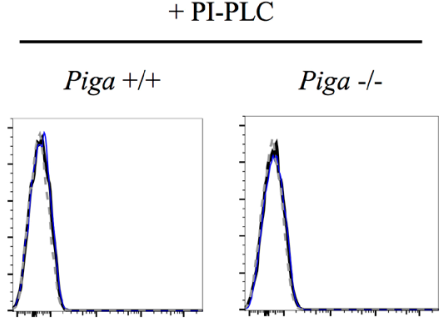

Pigu $+/+$

Pigu -/-
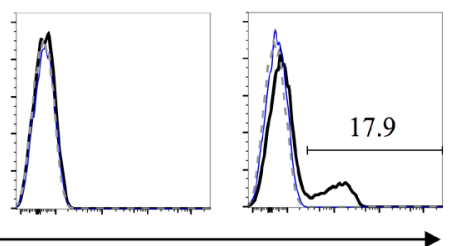

Figure 5. Generation of $\mathrm{GPI}^{+}$, GPI-AP${ }^{-}$primary $\mathrm{CD}^{+} \mathrm{T}^{-}$cells. (A). Schematic representation of Pigu floxed exon 2 showing the $\operatorname{lox} P$ sites (red triangles) and the positions of primers used for genotyping. (B). T cell specific disruption of Pigu exon 2. DNA was prepared from tail (lane 1), purified B cells (lane 2) or sorted $\mathrm{CD}^{+} \mathrm{GPI}^{-} \mathrm{T}$ cells (lane 3) of Pigu Tm1c/Tm1c Lck Cre ${ }^{+}$mouse and used in PCR with primers specific for Pigu exon 2 or Cre. (C). Splenocytes and purified $\mathrm{CD}^{+} \mathrm{T}$ cells were prepared from $\mathrm{Pigu}^{+/+}$and $\mathrm{Pigu}^{-1-}$ mice and stained for $\mathrm{CD} 48$ and either TCR or IgM. (D). FACS analysis of CD4 $4^{+} \mathrm{T}$ cells prepared from $\mathrm{Piga}^{++}, \mathrm{Piga}^{-/}, \mathrm{Pigu}^{+/+}$and $\mathrm{Pigu}^{-/-}$mice, treated or not with PI-PLC and stained with secondary antibody alone (blue lines) or with $\mathrm{T} 5 \mathrm{mAb}$ and secondary $\mathrm{Ab}$ (black lines). Dotted lines represent unstained samples.

phenotype of Pigu and Piga deficiency. Specifically, as illustrated in Figure 6(A), levels of anti-CD3E induced ${ }^{3} \mathrm{H}$-TdR uptake by $\mathrm{Pigu}^{+/+} \mathrm{CD} 4^{+} \mathrm{T}$ cells was comparable to or exceeded those by Pigu $^{-1-} \mathrm{CD}_{4}^{+} \mathrm{T}$ cells. Anti-CD3E induced IL-2 
A

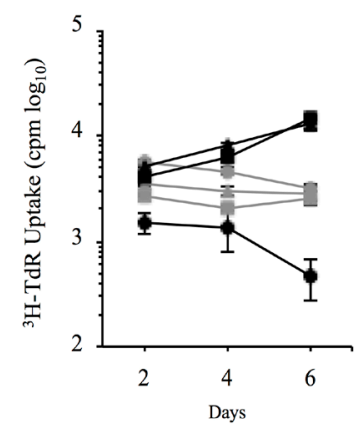

B

C

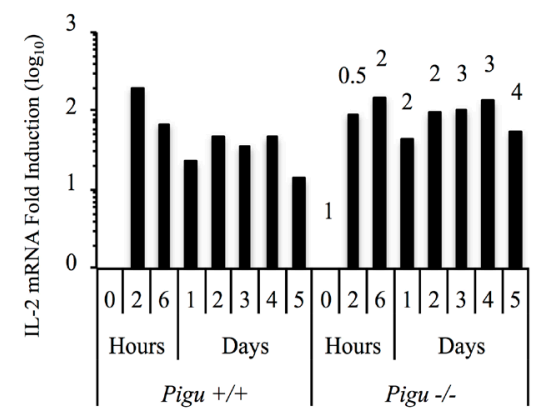

D

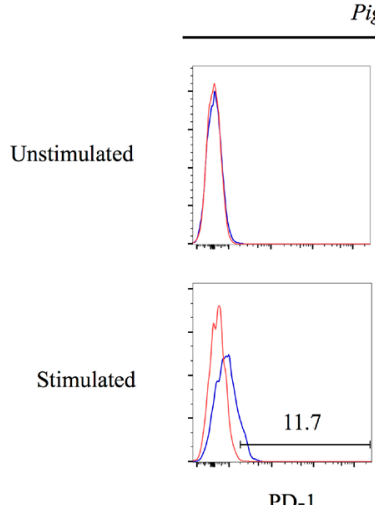

PD-1
Pigu $+/+$
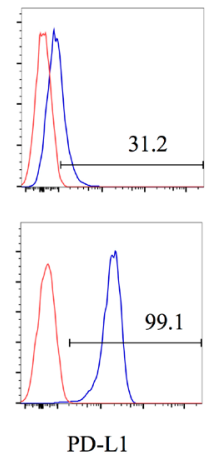

PD-L1

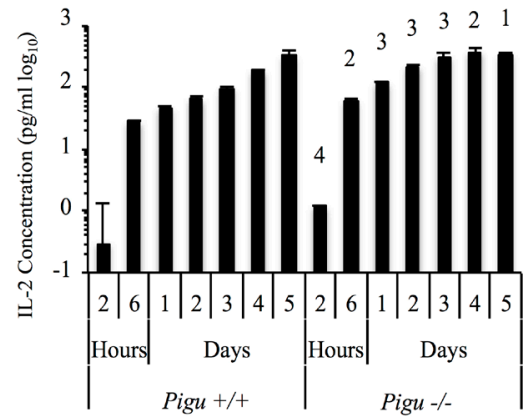

Pigu -/-
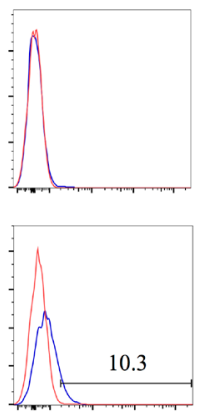

PD-1
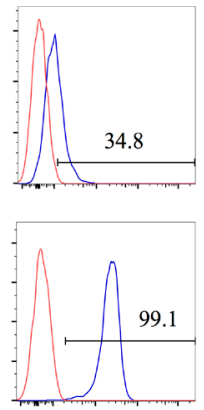

PD-L1

F

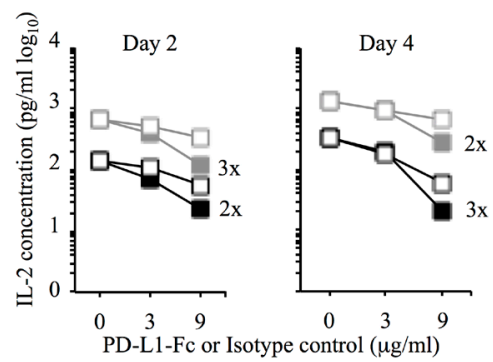

Figure 6. GPI expression attenuates TCR induced IL-2 production in primary $\mathrm{CD} 4^{+} \mathrm{T}$ cells. (A). $\mathrm{Pigu}^{+/+}$(black) and $\mathrm{Pigu}^{-/-}$(grey) $\mathrm{CD}^{+} \mathrm{T}$ cells were stimulated on plates pre-

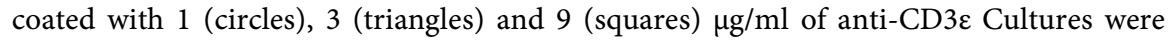
pulsed with $1 \mu \mathrm{g} / \mathrm{ml}{ }^{3} \mathrm{H}-\mathrm{TdR}$ at the indicated time points, harvested 6 hours later, and ${ }^{3} \mathrm{H}-\mathrm{TdR}$ uptake assessed using liquid scintillation spectroscopy. (B)-(C). Pigu $^{+/+}$and $\mathrm{Pigu}^{-1-} \mathrm{CD}^{+} \mathrm{T}$ cells were stimulated on plated precoated with $3 \mu \mathrm{g} / \mathrm{ml}$ of anti-CD3E and harvested at the indicated time points. IL- 2 mRNA fold induction was determined by 
ddPCR analysis (B) and IL-2 concentration was quantified by ELISA (C). In (B), the ratio $\mathrm{GPI}^{-} / \mathrm{GPI}^{+}$of IL-2 mRNA fold induction is indicated above each of the $\mathrm{GPI}^{-}$time points; and in (C), the ratio of $\mathrm{GPI}^{-} / \mathrm{GPI}^{+} \mathrm{IL}-2$ concentrations is indicated above each of the $\mathrm{GPI}^{-}$ time points. Ratios were rounded to the nearest whole number or fraction when appropriate. The means \pm standard errors of anti-CD3 $\varepsilon$ induced fold-increment of mRNA from $\mathrm{Pigu}^{-/-} \mathrm{CD}^{+}$primary T cells in 4 independent experiments, ranged from 1-3 \pm 0.3-1-fold. And the mean \pm standard error of the peak anti-CD3 $\varepsilon$ induced fold-increment of IL-2 levels from $\mathrm{Pigu}^{-1-} \mathrm{CD}^{+}$primary T cells in 3 independent experiments is $3 \pm 1$-fold. (D). PD-1 and PD-L1 levels on $\mathrm{Pigu}^{+/+}$and $\mathrm{Pigu}^{-{ }_{-}} \mathrm{CD} 4^{+} \mathrm{T}$ cells either unstimulated or stimulated for 20 hours on plates precoated with $1 \mu \mathrm{g} / \mathrm{ml}$ of anti-CD3E PD-1 or PD-L1 staining versus isotype control staining is illustrated with blue and red lines, respectively. (E). $\mathrm{Pigu}^{+/+}$(black) and $\mathrm{Pigu}^{-{ }_{-}}$(grey) $\mathrm{CD}^{+} \mathrm{T}$ cells were stimulated on plates precoated with 3 $\mu \mathrm{g} / \mathrm{ml}$ of anti-CD3 $\varepsilon$ alone, or with 3 or $9 \mu \mathrm{g} / \mathrm{ml}$ of PD-L1-Fc (closed squares) or its isotype control (open squares). Cultures were pulsed with $1 \mu \mathrm{g} / \mathrm{ml}{ }^{3} \mathrm{H}-\mathrm{TdR}$ at the indicated time points, harvested 6 hours later, and ${ }^{3} \mathrm{H}-\mathrm{TdR}$ uptake assessed using liquid scintillation spectroscopy. Results are presented as \% control with anti-CD3e set at $100 \%$. (F). Supernatants were collected from cultures in (E) and IL-2 concentrations measured by ELISA.

mRNA in $\mathrm{Pigu}^{--} \mathrm{CD}^{+} \mathrm{T}$ cells ranged within 0.5-3.8-fold of those levels in $\mathrm{Pigu}^{++} \mathrm{CD}^{+} \mathrm{T}$ cells (Figure 6(B)); and IL-2 levels in culture supernatants of $\mathrm{Pigu}^{-1-} \mathrm{CD}^{+} \mathrm{T}$ cells ranged from 1-4-fold of those in culture supernatants of $\mathrm{Pigu}^{+/+} \mathrm{CD}^{+} \mathrm{T}$ cells (Figure 6(C)).

Thus, the differential of anti-CD $3 \varepsilon$ induced IL-2 mRNA and IL-2 observed in Pigu $^{-/-}$versus Pigu $^{+/+} \mathrm{CD}_{4}^{+} \mathrm{T}$ cells is $10-50$-fold less relative to that observed in Piga $^{+}$versus Piga ${ }^{-} \mathrm{CD}^{+} \mathrm{T}$ cells (Figure 3, Figure 4 and Figure 6).

Notwithstanding, even a 2-4-fold increment of IL-2 in the surround was sufficient to impact PD-L1 mediated inhibition of anti-CD3 $\varepsilon$ induced ${ }^{3} \mathrm{H}$-TdR uptake by in $\mathrm{Pigu}^{-1-} \mathrm{CD} 4^{+} \mathrm{T}$ cells (Figure 6(E)). Importantly, both basal and anti-CD3e induced levels of expression of PD1 and PD-L1 are comparable in $\mathrm{Pigu}^{-{ }^{--}}$and $\mathrm{Pigu}^{+/+} \mathrm{CD}^{+} \mathrm{T}$ cells (Figure 6(D)). Further, and as for PD-L1 mediated inhibition of IL-2 in culture supernatants of anti-CD3ع stimulated Piga $^{-}$and $\mathrm{Piga}^{+}$ $\mathrm{CD} 4^{+} \mathrm{T}$ cells (Figure 4(B)), PD-L1 inhibits levels of IL-2 observed in supernatants of anti-CD3E induced $\mathrm{Pigu}^{-/-}$and $\mathrm{Pigu}^{+/+} \mathrm{CD} 4^{+} \mathrm{T}$ cells, comparably (Figure 6(F)).

In sum, the striking differential effects in the regulation of TCR induced DNA synthesis and IL-2 production in primary Piga and Pigu deficient primary CD4 $4^{+}$ $\mathrm{T}$ cells provide the first evidence that expression of free GPI functions to profoundly attenuate TCR signalling.

\section{Concluding Remarks}

The key resolve of this study is the formal demonstration that regulation of TCR induced DNA synthesis and IL-2 production in primary Piga and Pigu deficient primary $\mathrm{CD}^{+} \mathrm{T}$ cells provide the first evidence that expression of free GPI functions to profoundly attenuate TCR signalling. In this regard, it is of note that TCR stimulation of GPI-AP ${ }^{-}$primary $\mathrm{CD}^{+} \mathrm{T}$ cells results in 5-7-fold increases in IL-4 and IFN- $\gamma$ levels as well (not shown). However, neither is likely relevant to the phenotype described. The central role of IL-2 is underscored with the 
demonstration that $\mathrm{mAb}$ mediated inhibition of IL-2 reverses PD-L1 insensitivity.

The novel regulatory role of GPI could be central to mechanisms governing $\mathrm{T}$ cell homeostasis. We propose that an underpinning mechanism is governed by the imbalance of phosphoinositide (PtdIns) metabolism upon ablation of the GPI biosynthetic pathway. Phosphoinositides play a central and governing role in cell physiology; controlling membrane-cytosol interfaces [30] and regulation of cellular physiology [31]; generating metabolites that directly tether with cellular signalling machinery that regulates survival and metabolism [32] [33]; and regulating downstream TCR signalling machinery and the de novo induction of IL-2 [34]. The potential role of PI in regulating IL-2 production is modelled in Figure 7.

Previous reports demonstrate that GPI are expressed in the absence of a functional transamidase complex [15], and confirmed herein in primary $\mathrm{T}$ cells. A recent report demonstrates a role for ER-associated degradation in negative regulation of mature GPI anchor levels in the absence of a functional transamidase complex [35]. In contrast, it is unknown how ablation of GPI biosynthesis through disruption of the transferase complex impacts intracellular stores of PI and PtdIns. It is plausible that in the absence of a functional transferase complex, intracellular stores of PI metabolites re-equilibrate. The proposed subsequent impact on TCR induced signalling sequalae can be directly tethered to the signals emanating from the TCR that culminate in IL-2 production (Figure 7).

The proposed mechanism of PI-dependent enhanced growth/survival and differential growth factor production may be generalizable to the maintenance of cellular homeostasis of cell types other than lymphocytes; and the regulation of

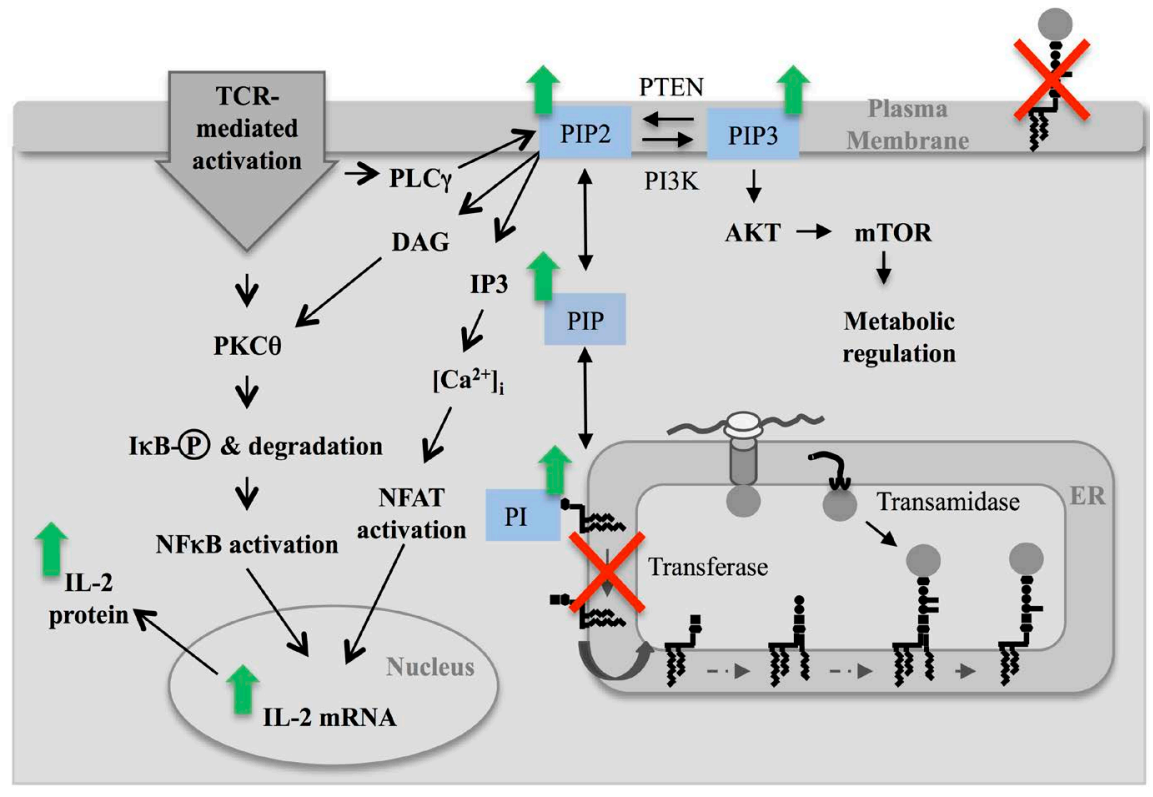

Figure 7. Modelling the role of PI metabolites in TCR induced IL-2 production. Delineation of a proposed re-equilibration of cellular stores of PI metabolites upon ablation of GPI-anchor biosynthesis; and the potential impact on the signalling sequelae of TCRinduced IL-2 production. 
cytokines, other than IL-2, which is not without precedent [36]. Insight into the potential relevance of this hypothetical is derived from studies focused on characterizing mechanism(s) underpinning establishment of clonal dominance in paroxysmal nocturnal hemoglobinuria ( $\mathrm{PNH}$ ) [37]. This acquired hematopoietic stem cell disorder correlates with preferential expansion and/or survival advantage leading to clonal dominance. Both intrinsic [38] and extrinsic [39] mechanism(s) have been postulated; neither have been formally proven as the exclusive mechanism. However, a pre-clinical study does formally demonstrate that the Piga lesion alone is not sufficient to support hematopoietic stem cell clonal dominance, rather, other genetic modifications are required [40] [41]. Further, the same multifactorial requirements apply to the high correlation of $\mathrm{PNH}$ patients developing AML, ALL, and CLL, many of which, although not exclusively, are derived from the Piga deficient hematopoietic stem cell clone [42]; and represent a frequency of incidence 80 -fold higher than in the general population [43] [44].

We speculate that PI metabolism and the effects of GPI-AP deficiencies on cellular physiology reported herein provide a new molecular lens to assess mechanisms governing the maintenance of cellular homeostasis and the onset of GPI-deficient non-neoplastic proliferative disease states as well as a potential contributor to the development of GPI-deficient neoplasms.

\section{Acknowledgements}

This work was supported by grants from the Medical Research Council of Canada \#MT-9735 and the Sunnybrook Research Institute \#SRI-VPR-2.

We would like to thank Drs. Jean Gariepy and Aaron Proteus at the Sunnybrook Research Institute for providing PD-L1.HIS and CEA-N.HIS; Kirishanthy Kathirkamathamby at the Sunnybrook Research Institute Antibody Facility for antibody purification and conjugation expertise; and the assistance of Gisele Knowles, Courtney McIntosh, Dr. Geneve Among and Paul Oleynik in flow cytometric analyses and cell sorting.

\section{Conflicts of Interest}

The authors declare no conflicts of interest regarding the publication of this paper.

\section{References}

[1] Ferguson, M.A.J., Hart, G.W. and Kinoshita, T. (2017) Chapter 12. Glycosylphosphatidylinositol Anchors. In: Rd, Varki, A., Cummings, R.D., Esko, J.D., Stanley, P., Hart, G.W., Aebi, M., Darvill, A.G., Kinoshita, T., Packer, N.H., Prestegard, J.H., Schnaar, R.L. and Seeberger, P.H., Eds., Essentials of Glycobiology, Cold Spring Harbor, New York, 137-150.

[2] Kinoshita, T. and Fujita, M. (2016) Thematic Review Series: Glycosylphosphatidylinositol (GPI) Anchors: Biochemistry and Cell Biology Biosynthesis of GPI-Anchored Proteins: Special Emphasis on GPI Lipid Remodeling. Journal of Li- 
pid Research, 57, 6-24. https://doi.org/10.1194/jlr.R063313

[3] Suzuki, K.G. (2015) New Insights into the Organization of Plasma Membrane and Its Role in Signal Transduction. International Review of Cell and Molecular Biology, 317, 67-96. https://doi.org/10.1016/bs.ircmb.2015.02.004

[4] Leyton, L., Diaz, J., Martinez, S., Palacios, E., Pérez, L.A. and Pérez, R.D. (2019) Thy-1/CD90 a Bidirectional and Lateral Signaling Scaffold. Frontiers in Cell and Developmental Biology, 7, 132. https://doi.org/10.1016/j.biocel.2010.09.001

[5] Elishmereni, M. and Levi-Schaffer, F. (2011) CD48: A Co-Stimulatory Receptor of Immunity. The International Journal of Biochemistry \& Cell Biology, 43, 25-28. https://doi.org/10.1073/pnas.0905217106

[6] van Zanten, T.S., Cambi, A., Koopman, M., Joosten, B., Figdor, C.G. and Garcia-Parajo, M.F. (2009) Hotspots of GPI-Anchored Proteins and Integrin Nanoclusters Function as Nucleation Sites for Cell Adhesion. Proceedings of the National Academy of Sciences of the United States of America, 106, 18557-18562.

https://doi.org/10.1073/pnas.0905217106

[7] Sesana, S., Re, F., Bulbarelli, A., Salerno, D., Cazzaniga, E. and Masserini, M. (2008) Membrane Features and Activity of GPI-Anchored Enzymes: Alkaline Phosphatase Reconstituted in Model Membranes. Biochemistry, 47, 5433-5440. https://doi.org/10.1021/bi800005s

[8] Lublin, D.M. and Coyne, K.E. (1991) Phospholipid-Anchored and Transmembrane Versions of Either Decay-Accelerating Factor or Membrane Cofactor Protein Show Equal Efficiency in Protection from Complement-Mediated Cell Damage. Journal of Experimental Medicine, 174, 35-44. https://doi.org/10.1084/jem.174.1.35

[9] Haziot, A., Rong, G.W., Bazil, V., Silver, J. and Goyert, S.M. (1994) Recombinant Soluble CD14 Inhibits LPS-Induced Tumor Necrosis Factor-Alpha Production by Cells in Whole Blood. The Journal of Immunology, 152, 5868-5876.

[10] Itzhaky, D., Raz, N. and Hollander, N. (1998) The Glycosylphosphatidylinositol-Anchored Form and the Transmembrane Form of CD58 Associate with Protein Kinases. The Journal of Immunology, 160, 4361-4366. https://doi.org/10.1194/jlr.R062760

[11] Muniz, M. and Riezman, H. (2016) Trafficking of Glycosylphosphatidylinositol Anchored Proteins from the Endoplasmic Reticulum to the Cell Surface. Journal of Lipid Research, 57, 352-360. https://doi.org/10.1194/jlr.R062760

[12] Saha, S., Anilkumar, A.A. and Mayor, S. (2016) GPI-Anchored Protein Organization and Dynamics at the Cell Surface. Journal of Lipid Research, 57, 159-175. https://doi.org/10.1194/jlr.R062885

[13] Zurzolo, C. and Simons, K. (2016) Glycosylphosphatidylinositol-Anchored Proteins: Membrane Organization and Transport. Biochimica et Biophysica Acta (BBA)-Biomembranes, 1858, 632-639. https://doi.org/10.1016/j.bbamem.2015.12.018

[14] Hochsmann, B., Murakami, Y., Osato, M., Knaus, A., Kawamoto, M., Inoue, N., Hirata, T., Murata, S., Anliker, M., Eggermann, T., Jager, M., Floettmann, R., Hollein, A., Murase, S., Ueda, Y., Nishimura, J.I., Kanakura, Y., Kohara, N., Schrezenmeier, H., Krawitz, P.M. and Kinoshita, T. (2019) Complement and Inflammasome Overactivation Mediates Paroxysmal Nocturnal Hemoglobinuria with Autoinflammation. Journal of Clinical Investigation, 129, 5123-5136.

https://doi.org/10.1172/JCI123501

[15] Wang, Y., Hirata, T., Maeda, Y., Murakami, Y., Fujita, M. and Kinoshita, T. (2019) Free, Unlinked Glycosylphosphatidylinositols on Mammalian Cell Surfaces Revi- 
sited. Journal of Biological Chemistry, 294, 5038-5049.

https://doi.org/10.1074/jbc.RA119.007472

[16] Freeman, G.J., Long, A.J., Iwai, Y., Bourque, K., Chernova, T., Nishimura, H., Fitz, L.J., Malenkovich, N., Okazaki, T., Byrne, M.C., Horton, H.F., Fouser, L., Carter, L., Ling, V., Bowman, M.R., Carreno, B.M., Collins, M., Wood, C.R. and Honjo, T. (2000) Engagement of the PD-1 Immunoinhibitory Receptor by a Novel B7 Family Member Leads to Negative Regulation of Lymphocyte Activation. Journal of Experimental Medicine, 192, 1027-1034. https://doi.org/10.1084/jem.192.7.1027

[17] Abdul-Wahid, A., Huang, E.H., Lu, H., Flanagan, J., Mallick, A.I. and Gariepy, J. (2012) A focused Immune Response Targeting the Homotypic Binding Domain of the Carcinoembryonic Antigen Blocks the Establishment of Tumor Foci in Vivo. International Journal of Cancer, 131, 2839-2851.

https://doi.org/10.1002/ijc.27582

[18] Haughn, L., Gratton, S., Caron, L., Sekaly, R.P., Veillette, A. and Julius, M. (1992) Association of Tyrosine Kinase p56 ${ }^{\text {lck }}$ with CD4 Inhibits the Induction of Growth through the $\alpha \beta$ T-Cell Receptor. Nature, 358, 328-331.

https://doi.org/10.1038/358328a0

[19] Takahama, Y., Ohishi, K., Tokoro, Y., Sugawara, T., Yoshimura, Y., Okabe, M., Kinoshita, T. and Takeda, J. (1998) Functional Competence of T Cells in the Absence of Glycosylphosphatidylinositol-Anchored Proteins Caused by T Cell-Specific Disruption of the Pig-A Gene. European Journal of Immunology, 28, 2159-2166. https://doi.org/10.1002/(SICI)1521-4141(199807)28:07\%3C2159::AID-IMMU2159 \%3E3.0.CO;2-B

[20] Boyman, O., Kovar, M., Rubinstein, M.P., Surh, C.D. and Sprent, J. (2006) Selective Stimulation of T Cell Subsets with Antibody-Cytokine Immune Complexes. Science, 311, 1924-1927. https://doi.org/10.1126/science.1122927

[21] Watanabe, R., Murakami, Y., Marmor, M.D., Inoue, N., Maeda, Y., Hino, J., Kangawa, K., Julius, M. and Kinoshita, T. (2000) Initial Enzyme for Glycosylphosphatidylinositol Biosynthesis Requires PIG-P and Is Regulated by DPM2. The EMBO Journal, 19, 4402-4411. https://doi.org/10.1093/emboj/19.16.4402

[22] Otani, H., Erdos, M. and Leonard, W.J. (1993) Tyrosine Kinase(s) Regulate Apoptosis and bcl-2 Expression in a Growth Factor-Dependent Cell Line. Journal of Biological Chemistry, 268, 22733-22736. https://doi.org/10.1016/S0021-9258(18)41588-8

[23] Broome, H.E., Dargan, C.M., Krajewski, S. and Reed, J.C. (1995) Expression of Bcl-2, Bcl-x, and Bax after T Cell Activation and IL-2 Withdrawal. The Journal of Immunology, 155, 2311-2317.

[24] Carter, L., Fouser, L.A., Jussif, J., Fitz, L., Deng, B., Wood, C.R., Collins, M., Honjo, T., Freeman, G.J. and Carreno, B.M. (2002) PD-1: PD-L Inhibitory Pathway Affects Both $\mathrm{CD}^{+}$and $\mathrm{CD}^{+} \mathrm{T}$ Cells and Is Overcome by IL-2. European Journal of Immunology, 32, 634-643.

https://doi.org/10.1002/1521-4141(200203)32:3\%3C634::AID-IMMU634\%3E3.0.CO $\underline{; 2-9}$

[25] Latchman, Y., Wood, C.R., Chernova, T., Chaudhary, D., Borde, M., Chernova, I., Iwai, Y., Long, A.J., Brown, J.A., Nunes, R., Greenfield, E.A., Bourque, K., Boussiotis, V.A., Carter, L.L., Carreno, B.M., Malenkovich, N., Nishimura, H., Okazaki, T., Honjo, T., Sharpe, A.H. and Freeman, G.J. (2001) PD-L2 Is a Second Ligand for PD-1 and Inhibits T Cell Activation. Nature Immunology, 2, 261-268. https://doi.org/10.1038/85330 
[26] Hazenbos, W.L., Murakami, Y., Nishimura, J., Takeda, J. and Kinoshita, T. (2004) Enhanced Responses of Glycosylphosphatidylinositol Anchor-Deficient T Lymphocytes. The Journal of Immunology, 173, 3810-3815.

https://doi.org/10.4049/jimmunol.173.6.3810

[27] Hong, Y., Ohishi, K., Kang, J.Y., Tanaka, S., Inoue, N., Nishimura, J., Maeda, Y. and Kinoshita, T. (2003) Human PIG-U and Yeast Cdc91p Are the Fifth Subunit of GPI Transamidase That Attaches GPI-Anchors to Proteins. Molecular Biology of the Cell, 14, 1780-1789. https://doi.org/10.1091/mbc.e02-12-0794

[28] Allen, J.M., Forbush, K.A. and Perlmutter, R.M. (1992) Functional Dissection of the lck Proximal Promoter. Molecular and Cellular Biology, 12, 2758-2768. https://doi.org/10.1128/MCB.12.6.2758

[29] Tomavo, S., Couvreur, G., Leriche, M.A., Sadak, A., Achbarou, A., Fortier, B. and Dubremetz, J.F. (1994) Immunolocalization and Characterization of the Low Molecular Weight Antigen (4-5 kDa) of Toxoplasma gondii That Elicits an Early IgM Response upon Primary Infection. Parasitology, 108, 139-145. https://doi.org/10.1017/S0031182000068220

[30] Dickson, E.J. and Hille, B. (2019) Understanding Phosphoinositides: Rare, Dynamic, and Essential Membrane Phospholipids. Biochemical Journal, 476, 1-23. https://doi.org/10.1042/BCJ20180022

[31] Balla, T. (2013) Phosphoinositides: Tiny Lipids with Giant Impact on Cell Regulation. Physiological Reviews, 93, 1019-1137. https://doi.org/10.1152/physrev.00028.2012

[32] Pompura, S.L. and Dominguez-Villar, M. (2018) The PI3K/AKT Signaling Pathway in Regulatory T-Cell Development, Stability, and Function. Journal of Leukocyte Biology, 103, 1065-1076. https://doi.org/10.1002/JLB.2MIR0817-349R

[33] Myers, D.R., Wheeler, B. and Roose, J.P. (2019) mTOR and Other Effector Kinase Signals That Impact T Cell Function and Activity. Immunological Reviews, 291, 134-153. https://doi.org/10.1111/imr.12796

[34] Cantrell, D.A. (2002) T-Cell Antigen Receptor Signal Transduction. Immunology, 105, 369-374. https://doi.org/10.1046/j.1365-2567.2002.01391.x

[35] Wang, Y., Maeda, Y., Liu, Y.S., Takada, Y., Ninomiya, A., Hirata, T., Fujita, M., Murakami, Y. and Kinoshita, T. (2020) Cross-Talks of Glycosylphosphatidylinositol Biosynthesis with Glycosphingolipid Biosynthesis and ER-Associated Degradation. Nature Communications, 11, Article No. 860. https://doi.org/10.1038/s41467-020-14678-2

[36] Hosokawa, K., Kajigaya, S., Keyvanfar, K., Qiao, W., Xie, Y., Biancotto, A., Townsley, D.M., Feng, X. and Young, N.S. (2017) Whole Transcriptome Sequencing Identifies Increased CXCR2 Expression in PNH Granulocytes. British Journal of Haematology, 177, 136-141. https://doi.org/10.1111/bjh.14502

[37] Hill, A., DeZern, A.E., Kinoshita, T. and Brodsky, R.A. (2017) Paroxysmal Nocturnal Haemoglobinuria. Nature Reviews Disease Primers, 3, Article No. 17028. https://doi.org/10.1038/nrdp.2017.28

[38] Kunyaboon, R., Wanachiwanawin, W., Y, U.P., Thedsawad, A. and Taka, O. (2012) Mechanism of Paroxysmal Nocturnal Hemoglobinuria Clonal Dominance: Possible Roles of Different Apoptosis and CD8+ Lymphocytes in the Selection of Paroxysmal Nocturnal Hemoglobinuria Clones. Hematology/Oncology and Stem Cell Therapy, 5, 138-145. https://doi.org/10.5144/1658-3876.2012.138

[39] Gargiulo, L., Papaioannou, M., Sica, M., Talini, G., Chaidos, A., Richichi, B., Nikolaev, A.V., Nativi, C., Layton, M., de la Fuente, J., Roberts, I., Luzzatto, L., Notaro, 
R. and Karadimitris, A. (2013) Glycosylphosphatidylinositol-Specific, CD1d-Restricted T Cells in Paroxysmal Nocturnal Hemoglobinuria. Blood, 121, 2753-2761. https://doi.org/10.1182/blood-2012-11-469353

[40] Rosti, V., Tremml, G., Soares, V., Pandolfi, P.P., Luzzatto, L. and Bessler, M. (1997) Murine Embryonic Stem Cells without Pig-A Gene Activity Are Competent for Hematopoiesis with the PNH Phenotype but Not for Clonal Expansion. Journal of Clinical Investigation, 100, 1028-1036. https://doi.org/10.1172/JCI119613

[41] Kulasekararaj, A.G. (2017) Clonal Dominance of PNH- Another Piece to the Jigsaw. British Journal of Haematology, 177, 9-10. https://doi.org/10.1111/bjh.14552

[42] Chen, Y., Tao, S., Deng, Y., Song, L. and Yu, L. (2015) Chronic Myeloid Leukemia Transformation in a Patient with Paroxysmal Nocturnal Hemoglobinuria: A Rare Case Report with Literature Review. International Journal of Clinical and Experimental Medicine, 8, 8226-8229.

[43] Harris, J.W., Koscick, R., Lazarus, H.M., Eshleman, J.R. and Medof, M.E. (1999) Leukemia Arising Out of Paroxysmal Nocturnal Hemoglobinuria. Leukemia \& Lymphoma, 32, 401-426. https://doi.org/10.3109/10428199909058399

[44] Isoda, A., Ogawa, Y., Matsumoto, M. and Sawamura, M. (2009) Coexistence of Paroxysmal Nocturnal Hemoglobinuria $(\mathrm{PNH})$ and Acute Lymphoblastic Leukemia (ALL): Is PNH a Prodrome of ALL? Leukemia Research, 33, e3-e5.

https://doi.org/10.1016/j.leukres.2008.05.016 